\title{
The Future of Shareholder Democracy in the Shadow of the Financial Crisis
}

\author{
Alan Dignam*
}

"The rule is, jam to-morrow and jam yesterday - but never jam today."

"It must come sometimes to 'jam to-day'," Alice objected.

"No, it can't," said the Queen.

"It's jam every other day: to-day isn't any other day, you know."

"I don't understand you," said Alice. "It's dreadfully confusing!"1

\section{TABLE OF CONTENTS}

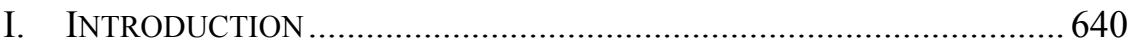

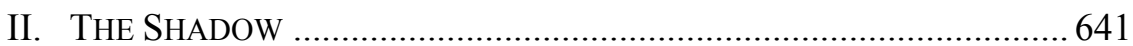

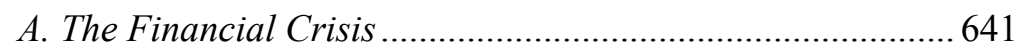

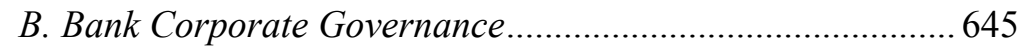

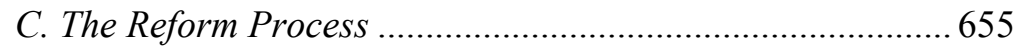

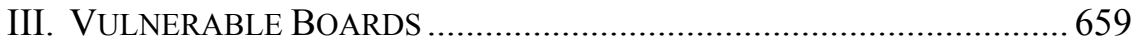

A. Directors' Discretion ....................................................6 660

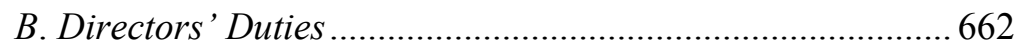

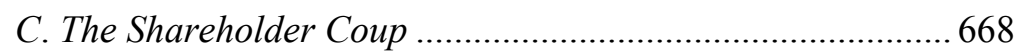

D. The Larger Context: Cultural and Theoretical Change ..... 672

IV. OWNERLESS CORPORATIONS OR SHAREHOLDERS ON STEROIDS?. 682

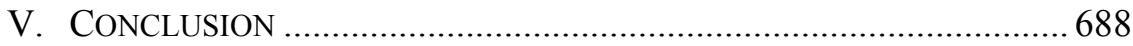

\footnotetext{
* Professor of Corporate Law, School of Law, Queen Mary, University of London. With thanks to all the participants in the 2012 Berle Symposium and to Marc Moore and Charles O'Kelley for pulling off a remarkable event. In particular, my thanks go to David Westbrook, Lynn Stout, Chris Bruner, Wolf-Georg Ringe, John Lowry, and Steven Schwarcz for comments on earlier drafts.

1. Lewis Carroll, Through the Looking Glass and What Alice Found There 36 (1979). Here we encounter our first barrier to Anglo-American communication. Jam in Britain and Ireland means jelly in the United States (I think). Another much more eminent Irishman, George Bernard Shaw, was once attributed as observing: "England and America are two countries separated by a common language." Who knew fruit preserves could be so interesting and confusing?
} 


\section{INTRODUCTION}

This Article argues that the U.K. regulatory response to the financial crisis, in the form of "stewardship" and shareholder engagement, is an error built on a misunderstanding of the key active role shareholders played in the enormous corporate governance failure represented by the banking crisis. Shareholders' passivity, ${ }^{2}$ rather than activity, has characterized the reform perception of the shareholder role in corporate governance. This characterization led to the conclusion that if only they were more active ${ }^{3}$ they would be more responsible "stewards" of the corporation. If, as this Article argues, shareholder activity was part of the problem in the banks, then encouraging increased shareholder action and exporting it outside of banks, as we have subsequently done in the United Kingdom, risks a wider systemic corporate governance failure. In short, we have learned the wrong lesson about shareholders from the banking crisis.

In setting out this proposition, this Article proceeds in five parts, which includes this introduction, Part I. Then, Part II, "The Shadow," examines the corporate governance issues that were present in the U.K. banks that preceded and contributed to the financial crisis. Part III, "Vulnerable Boards," examines the historic vulnerability of U.K. boards of directors to shareholder power given the legal, cultural, theoretical, and practical constraints on their discretion to run the company. In particular, this Part argues that the Takeover Panel, in eliminating board discretion, has had a strong dampening effect on the development of board discretion in the United Kingdom.

In Part IV, "Ownerless Corporations or Shareholders on Steroids," this Article considers the proposition that rather than the regulatory assumption that the United Kingdom has a passive ownerless-corporation problem, the United Kingdom has, as illustrated by the banking collapse and the more recent shareholder "spring," a growing problem of shareholders on steroids. Combinations of newer, passive overseas sharehold-

2. U.K. shareholders have historically tended toward passivity internally except in crisis where exit is the usual response. See Brian R. Cheffins, The Stewardship Code's Achilles' Heel (Univ. of Cambridge Faculty of Law, Working Paper No. 28, 2011), available at http://papers.ssrn.com/sol3/ papers.cfm?abstract_id $=1837344$

3. The assumption is that if shareholders were more active in exercising control over the companies they invested in, their increased activity would lead to a positive longer-term approach to their investments. See generally John KaY, U.K. DEP'T FOR Bus. InNOVATION \& SKILls, The KaY REVIEW of UK EQUiTy MARKETS AND LONG-TERm DECISION MAKING: FinAL REPORT (2012), available at $\mathrm{http} / /$ www.bis.gov.uk/assets/biscore/business-law/docs/k/12-917-kay-review-of-equitymarkets-final-report.pdf [hereinafter KAY, FINAL REPORT]; DAVID WALKER, A REVIEW OF CORPORATE GOVERNANCE IN UK BANKS AND Other FinANCIAL INDUSTRY EnTITIES: Final RECOMMENDATIONS (2009), available at http://www.hm-treasury.gov.uk/d/walker_review_261 109.pdf. 
ers and vulnerable boards have allowed activist shareholders and traders to focus on the short term. Regulatory responses such as stewardship and shareholder empowerment are inappropriate because they risk accelerating this short-term trend.

Part V concludes by offering technical solutions in removing key problematic agency-cost-reduction measures such as the takeover panel, and allowing a judicial balance to re-emerge in the development of directors' discretion to manage the company. These solutions will not, however, fix the systemic flaw in a corporate governance system designed around current shareholders with a diminished role for the board of directors, the employees, and the community. A rebalancing is needed, whereby both the board and the state are reinvigorated in terms of their influence on a rematerialized corporation.

\section{THE SHADOW}

The financial crisis has cast a particular shadow over the recent general corporate governance reform in the United Kingdom, resulting in an emphasis on encouraging the long-term engagement of shareholders through the nebulous concept of stewardship. Encouraging stewardship is problematic in the U.K. context because of the deep imbalance in the power structure of U.K. companies, which has focused on current shareholders to the detriment of board independence. This imbalance makes corporations particularly vulnerable to shareholder activism, which may be focused on short-term gains to the detriment of the longer-term interests of the company. The corporate governance problems in U.K. banks, which led to the financial crisis, as well as the regulatory-reform response provide an illustration of how short-term shareholder activism can be problematic and how the regulatory response, in terms of stewardship and shareholder empowerment, is misplaced. This Article considers these issues in turn.

\section{A. The Financial Crisis}

Banks have certain unique features as organizations. First, banks operate with an explicit and implicit state guarantee, which heavily subsidizes their activities. ${ }^{4}$ Without this subsidy, most U.K. banks would be unable to trade on the scale they do. ${ }^{5}$ Second, this government guarantee was explicitly exercised in the case of three major and two minor U.K.

4. See Piergiorgio Alessandri \& Andrew G. Haldane, Banking on the State, BANK OF ENG. (Nov. 2009), http:/www.bankofengland.co.uk/publications/speeches/2009/speech409.pdf; Andrew G. Haldane, The $\$ 100$ Billion Question, BANK OF ENG. 4-5 (Mar. 2010), http://www.bankofeng land.co.uk/publications/speeches/2010/speech433.pdf.

5. Alessandri \& Haldane, supra note 4. 
banks in 2008. ${ }^{6}$ Consequently, these banks now effectively operate as state-owned enterprises. Third, because of their history and funding, banks have significantly different internal corporate governance issues, as compared to other large listed companies. ${ }^{7}$ Their unique status also provides an example of the extremes within the U.K. privateshareholder-agent model and allows some insight into why shareholderfocused solutions may be part of the corporate governance problem rather than the solution.

Between the 1970s and the global financial crisis in 2008, a combination of technological advances and the removal of capital controls on an almost global scale concentrated the world's financial capital in just 145 banks. $^{8}$ Almost all of these banks were universal banks, with business across the full range of the financial sector, holding total firm assets of over $£ 100$ billion each. ${ }^{9}$ To put this capital concentration in perspective, there are some twenty-four nation-states that do not have individual GDPs in excess of $£ 100$ billion. ${ }^{10}$ By 2008 , the world's five largest banks held $16 \%$ of global-banking assets. ${ }^{11}$ The U.K. banking sector in particular had grown enormously, from 50\% of the country's GDP in the 1970 s to $500 \%$ by $2010 .^{12}$

The growth of these banks and the public subsidy of their activities were intricately linked. Mervyn King, the governor of the Bank of England, described it in 2010:

Institutions supplying such services are quite simply too important to fail. Everyone knows it. So, highly risky banking institutions enjoy implicit public sector support. In turn, public support incentivises banks to take on yet more risk, knowing that, if things go well, they will reap the rewards while the public sector will foot the bill if things go wrong. Greater risk begets greater size, most probably greater importance to the functioning of the economy, higher im-

6. See Treasury Comm., Banking Crisis: Dealing with the Failure of the UK Banks, 2008-9, H.C. 416 (U.K.), available at http://www.publications.parliament.uk/pa/cm200809/ cmselect/cmtreasy/416/416.pdf; Brian Wheeler \& Justin Parkinson, As It Happened: Bank Rescue Plan, BBC News (Oct. 8, 2008), http://news.bbc.co.uk/1/hi/uk politics/7658518.stm.

7. These corporate governance issues are discussed infra Part II.B.

8. Haldane, supra note 4, at 19.

9. Id.

10. See The World Factbook, CENT. INTELLIGENCE AGENCY, https://www.cia.gov/library/ publications/the-world-factbook (last visited Nov. 18, 2012).

11. Alessandri \& Haldane, supra note 4 , at 15.

12. TREASURY COMM., TOO IMPORTANT TO FAIL-TOO IMPORTANT TO IGNORE, 2009-10, H.C. 261-I, at 3 (U.K.), available at http://www.publications.parliament.uk/pa/cm200910/cmselect/ cmtreasy/261/261i.pdf. 
plicit public subsidies, and hence yet larger incentives to take risk described by Martin Wolf as the "financial doomsday machine.","

The significance of each of these banks was not just that they were "too big to fail" (TBTF), but also that a government bailout of a TBTF bank would still have a destabilizing systemic effect on the global financial system. In other words, the sizes of the banks meant that a government could not safely handle the collapse of one TBTF bank or, in a worst case scenario, manage the failure of multiple TBTF banks, even with a coordinated international effort. ${ }^{14}$

By 2007, this "doomsday machine" nearly achieved the goal of its internal systemic logic. Artificially low interest rates first fuelled a boom. Then, the collapse of the U.S. housing prices by the same year led to the crisis in weak U.S. mortgage-backed securities (subprime), which had been widely sold to and insured throughout the world's major financial institutions. ${ }^{15}$ Major financial institutions began to struggle as high-debt and low-equity ratios left them seriously exposed to subprime losses. ${ }^{16}$ By August 2007, central banks around the world were pumping liquidity into the financial system as interbank lending began to dry up amid fears of a TBTF collapse. ${ }^{17}$ In September 2007, the U.K. bank Northern Rock had to be supported by the Bank of England, which led to a run on Northern Rock-the first on a U.K. bank in 150 years. ${ }^{18}$ In 2008, as banks and their insurers began to announce major subprime-related losses, the Bank of England widened its financial support for banks and lowered interest rates. ${ }^{19}$ As the crisis intensified, the government nationalized Northern Rock. ${ }^{20}$

The collapse of Lehman Brothers in September 2008 turned a crisis into a near catastrophe by revealing the interconnectedness of the major financial institutions' liabilities. ${ }^{21}$ Shocked by this revelation, investors

13. Mervyn King, Governor, Bank of Eng., Second Bagehot Lecture at the Buttonwood Gathering: Banking: From Bagehot to Basel, and Back Again 9 (Oct. 25, 2010) (transcript available at http://www.bankofengland.co.uk/publications/speeches/2010/speech455.pdf).

14. See Haldane, supra note 4, at 19.

15. Edward Luce, Few Escape Blame Over Subprime Explosion, Fin. TiMES (May 6, 2012), http://www.ft.com/cms/s/0/1d2c749a-39d9-11de-b82d-00144feabdc0.html\#axzz1hvORqgNa.

16. See generally Roger C. Altman, The Great Crash, 2008: A Geopolitical Setback for the West, FOREIGN AFF., Jan.-Feb. 2009, at 2, available at http://tomweston.net/TheGreatCrash.pdf.

17. See Northern Rock, HM TREASURY (Nov. 2010), http://www.hm-treasury.gov.uk/ fin_stability_nr.htm.

18. See id.

19. See Nat'l Audit Office, HM Treasury, The Nationalisation of Northern Rock, 2008-9, H.C. 298 (U.K.), available at http://www.nao.org.uk//idoc.ashx?docId=e6deeff5-34b949f1-8a4e-ab2ba3bd766f\&version=-1.

20. Id.

21. See The Collapse of Lehman Brothers, TELEGRAPH (Sept. 11, 2009), http://www.tele graph.co.uk/finance/financialcrisis/6173145/The-collapse-of-Lehman-Brothers.html. 
withdrew money from the world's financial system on an unprecedented scale. $^{22}$ In an effort to prevent the collapse of the financial system, the world's central banks pumped massive levels of funding into the system. ${ }^{23}$ As the major U.K. bank HBOS neared collapse, it merged with Lloyds TSB, and the government nationalized Bradford \& Bingley. ${ }^{24}$ Within months, three TBTF U.K. banks, HBOS, Lloyds TSB, and Royal Bank of Scotland (RBS), had been effectively nationalized. ${ }^{25}$ By the end of 2008, the Financial Times Stock Exchange Index 100 (FTSE) had lost nearly a third of its value as the crisis tipped the United Kingdom into recession, and unemployment rose by record levels. ${ }^{26}$ Countries around the world felt similar impacts as governments intervened to save their financial sectors from collapse. ${ }^{27}$ In the United Kingdom, the government's financial commitment to its banking sector reached over $70 \%$ of GDP by $2009 .^{28}$ By 2010 , nearly a quarter of global GDP had been provided as state support to banks. ${ }^{29}$ By 2011 , what began as a private sector crisis was increasingly becoming a general crisis, and the U.K. government slashed public sector spending to deal with the cost of the crisis, which had significantly decreased the country's revenue. ${ }^{30}$ Public and private job losses, education spending cuts, library closures, social welfare cuts, and pensions cuts were, and still are, all closely associated in the public mind with the cost of rescuing the banking sector. ${ }^{31}$

In particular, bankers' remuneration became and remains a perpetual and incendiary corporate governance issue in the United Kingdom. ${ }^{32}$ Greed and reward for failure was and is strongly associated with bank-

22. See DPA News Agency, Central Banks Intervene in Financial Markets, DeUTSCHE WeLLE (Sept. 18, 2008), http://www.dw.de/central-banks-intervene-in-financial-markets/a-3653694-1; see also News Release, Bank of Eng., Recapitalisation of the UK Banking System (Oct. 8, 2008), available at $\mathrm{http} / / / \mathrm{www} . b a n k o f e n g l a n d . c o . u k /$ publications/news/2008/066.htm; Press Notice, HM Treasury, Financial Support to the Banking Industry (Oct. 8, 2008), available at http://webarch ive.nationalarchives.gov.uk/+/http://www.hm-treasury.gov.uk/press_100_08.htm.

23. See DPA News Agency, supra note 22.

24. See generally TREASURY COMM., supra note 6.

25. See Timeline: Credit Crunch to Downturn, BBC News, http://news.bbc.co.uk/1/hi/7521 250.stm (last updated Aug. 7, 2009).

26. See id.

27. See TREASURY COMM., supra note 12 , at 3.

28. See Alessandri \& Haldane, supra note 4, at 23.

29. See id.

30. See generally Mervyn King, Governor, Bank of Eng., Speech to Scottish Business Oranizations at Edinburgh (Oct. 20, 2009) (transcript available at http://www.bankofengland.co.uk/pub lications/Documents/speeches/2009/speech406.pdf).

31. See id.

32. See generally Charlotte Villiers, Controlling Executive Pay: Institutional Investors or Distributive Justice?, 10 J. CORP. L. STUD. 309 (2010); see also Elizabeth Rigby \& Kate Burgess, Cable Outlines Plans to Curb Top Pay, Fin. TIMES (Jan. 23, 2012), http://www.ft.com/cms/s/0/ 6d43b768-45fc-11e1-9592-00144feabdc0.html\#axzz1kMzTiGAG. 
ing-sector remuneration. ${ }^{33}$ More significantly, in terms of the regulatory response, remuneration and risk taking were deeply interlinked with collapsed banks as report after report connected remuneration incentives and dangerous risk taking. ${ }^{34}$ Shareholders either seemed to collude in this short-term risk taking, or they exited the market upon realizing the extent of the risk. ${ }^{35}$ In short, the financial crisis revealed that U.K. banks had some significant corporate governance problems.

\section{B. Bank Corporate Governance}

Four observations concerning ownership and control distinguish the corporate governance of banks from corporate governance of other listed companies.

First, in broad terms, banks are not of a uniform type. Some are retail banks; some are universal banks carrying out the full range of retail, business, corporate, private, and investment banking; and some are pure investment banks focused mostly on activities within the financial markets. ${ }^{36}$ Although retail banks collapsed due to governance problems, ${ }^{37}$ the universal and investment banks created the market conditions for the collapse of retail banks. Therefore, this Article focuses on the larger universal and investment banks - the TBTF players. Universal banks have a de facto division within the corporate group between investment banking and the rest of the bank. In the run-up to the financial crisis, most of the excessive risk taking relating to remuneration and most of the universal

33. See Becky Barrow, Bosses of Banks Saved by Taxpayer Earn More Now Than Before the Crisis, MailOnline (Sept. 5, 2011, 5:41 PM), http://www.dailymail.co.uk/news/article2033744/Bosses-banks-saved-taxpayer-earn-crisis.html; see also James Lyons, Lloyds Banking Boss Eric Daniels Set for £2million Bonus, MIRROR (Jan. 13, 2011), http://www.mirror.co.uk/news/uknews/lloyds-banking-boss-eric-daniels-103934; RBS Boss Stephen Hester Rejects £1Million Bonus, BBC News (Jan. 30, 2012, 6:07 ET), http://www.bbc.co.uk/news/uk-16783571; Aislinn Simpson, Sir Fred Goodwin Attack: Bank Bosses Are Criminals Group Claims Responsibility, TELEGRAPH (Mar. 25, 2009), http://www.telegraph.co.uk/finance/newsbysector/banksandfinance/5048091/SirFred-Goodwin-attack-Bank-Bosses -Are-Criminals-group-claims-responsbility.html.

34. See generally TREASURY COMM., BANKING CRISIS: REFORMING CORPORATE GOVERNANCE AND PAY IN THE CITY, 2008-9, H.C. 519 (U.K.), available at http://www.publica tions.parliament.uk/pa/cm200809/cmselect/cmtreasy/519/519.pdf; FIN. SERVS. AUTH., THE TURNER REview: A REgulatory RESPONSE TO THE Global BANKING CRISIS (2009), available at http://www.fsa.gov.uk/pubs/other/turner_review.pdf; INDEP. COMM'N ON BANKING, FINAL REPORT: RECOMMENDATIONS (2011), available at http://www.ecgi.org/documents/icb_final_report_12sep 2011.pdf; WALKER, supra note 3.

35. See INDEP. COMM'N ON BANKING, supra note 34, at 3-31; see also WALKER, supra note 3, at $26,136-37$.

36. See Andrew W. Mullineux \& Victor Murinde, Handbook of International BANKING 3-5 (2003).

37. See generally John Neil Marshal et al., Placing the Run on Northern Rock, 12 J. ECON. GEO. 157 (2012). 
banks' shadow-power base lay within the investment-banking division. ${ }^{38}$ As a result, universal banks had an unusual de facto governance structure that focused their general interests and rewards on high-return but highrisk activities in the investment banking division and on the employees who ran or contributed significantly to these high risks and returns. ${ }^{39}$ For example, despite the seemingly powerful chief executive of RBS, Fred "the Shred" Goodwin, ${ }^{40}$ the head of investment banking, Johnny Cameron, was largely free to run the investment banking division as he saw fit. ${ }^{41}$ The same was true of Bob Diamond at Barclays' investment banking division. ${ }^{42}$

After leaving RBS and agreeing with the U.K. Financial Services Authority (FSA) not to carry out any "significant influence function" or "undertake any further full-time employment in the financial-services industry," in return for the FSA dropping a disciplinary action against him, Cameron was quoted as saying:

Personally, I really enjoyed my job with the only flaw being that I really disliked my boss [Goodwin] — but he didn't interfere very much. ... In my wildest dreams I didn't think I would have the biggest corporate bank in the world to run ... so putting up with Fred was a small price to pay. ${ }^{43}$

In addition to the division within banks, the banks' powerful key employees, who were in many cases much more highly paid than executive board members, operated "significantly below board level." 44 Indeed, the FSA, in its 2011 report on the collapse of RBS, considered dysfunctional internal governance a significant factor in the failure of the bank. ${ }^{45}$

38. See generally INDEP. COMM'N ON BANKING, supra note 34, at 10, 12.

39. Simon Bowers \& Nick Kochan, Former RBS Investment Banking Boss Heads off FSA Criticism of Role in Crisis, GUARDIAN (Dec. 11, 2011), http:/www.guardian.co.uk/business/ 2011/dec/11/rbs-banking-boss-crisis-fsa; see also Fin. SERVs. AUTH., THE FAILURE OF THE ROYAL BANK OF SCOTLAND (2011), available at http://www.fsa.gov.uk/pubs/other/rbs.pdf (discussing the problematic corporate governance arrangements within RBS).

40. Profile: Fred Goodwin, BBC News (Jan. 31, 2012), http://www.bbc.co.uk/news/business16822439.

41. See Bowers \& Kochan, supra note 39; see also FIN. SERVS. AUTH., supra note 39.

42. See Ben Chu, Bob Diamond - A Very Dangerous Banker, InDEPENDENT (Sept. 9, 2010), $\mathrm{http} / /$ www.independent.co.uk/opinion/commentators/ben-chu-bob-diamond-a-very-dangerous-ban ker-2074033.html. Barclays' wider interests are so closely associated with investment banking that Bob Diamond became the bank's chief executive in 2010. See Robert Peston, HSBC's Green Becomes Trade Minister and Diamond to Run Barclays, BBC News (Sept. 7, 2010), http://www.bbc.co.uk/blogs/thereporters/robertpeston/2010/09/hsbcs_green_becomes_trade_mini.ht $\mathrm{ml}$.

43. Bowers \& Kochan, supra note 39.

44. TREASURY COMM., supra note 34, at 14.

45. Id. at 107-09. On the general problems of bank governance, see Fin. SERVS. AuTH., supra note 39; WALKER, supra note 3. 
Second, U.K. and U.S. investment banks used to be partnerships, and this acted as an internal legal, financial, and cultural constraint on risk taking. ${ }^{46}$ When a partners' own capital was at risk, risk taking was curtailed ${ }^{47}$ From the 1970 s onward, these investment banks converted to limited liability corporations, which had significant evolutionary effects on the banking sector as a whole. ${ }^{48}$ Additionally, significant developments in financial theory assisted this evolution. Robert Merton's risk model demonstrated the huge advantages banks could gain from limited liability as long as they were prepared to increase their risk profiles. ${ }^{49}$ Limited liability assisted in the conversion of a prudential internal culture into a high-risk one because it enhanced the ability to take on risks free from joint and several liability and it allowed them to advantageously dissipate their then-unnecessary capital reserves. While these changes transferred risk to the state guarantors, they also allowed the banks' former partners to retain control of the investment banks so that in effect an employee-oriented power-and-reward culture remained. ${ }^{50}$ As Haldane noted, "[j] oint stock banking with limited liability puts ownership in the hands of a volatility junkie."

As time went by, U.K. and U.S. investment banks expanded their range of banking activities to compete with universal banks. ${ }^{52}$ This change also affected the universal banks. To remain competitive, some universal banks bought investment banks, while others hired teams from investment banks or mimicked the risk-taking activity and culture of the investment banks. ${ }^{53}$ By the beginning of the twenty-first century, investment banking, whether it occurred within a universal bank or an invest-

46. See generally Alan D. Morrison \& William J. Wilhelm, Jr., The Demise of InvestmentBanking Partnerships: Theory and Evidence, 63 J. Fin. 311 (2008).

47. See id.

48. See id.

49. See Robert C. Merton, The Pricing of Corporate Debt: The Risk Structure of Interest Rates, 29 J. FIN. 449 (1974)

50. See Andrew G. Haldane, Exec. Dir., Bank of Eng., Speech at the Wincott Annual Memorial Lecture: Control Rights (and Wrongs) 12 (Oct. 24, 2011) (transcript available at http://www.bankof england.co.uk/publications/speeches/2011/speech525.pdf).

51. Id. at 6 .

52. See generally Richard S. Grossman, Unsettled Account: The Evolution of BANKING IN THE INDUSTRIALIZED WORLD SINCE 1800, 251-90 (2010); see also Is There a Future? The Loneliness of the Independent Wall Street Bank, ECONOMIST (Sept. 18, 2008), http://www.economist.com/node/12274054? source=hptextfeature\&story id=12274054; Robert Teitelman, Bob Diamond and the Fall and Rise of the Universal Banking, DEAL ECONOMY (Sept. 9, 2010, 12:45 PM), http://www.thedeal.com/thedealeconomy/bob-diamond-and-the-fall-and-rise-ofuniversal-banking.php.

53. Is There a Future?, supra note 52. 
ment bank, was the focus of power, risk, and reward within the entire banking system. ${ }^{54}$

This risk revolution brought enormous benefits to the employees in investment banking without those employees necessarily taking on any real liability for the risks they were taking. ${ }^{55}$ In 2008, witnesses before the House of Commons Treasury Select Committee on Banking generally agreed that the short-term cash-bonus remuneration culture that dominated the investment-banking industry played a significant role in focusing employees on high-risk, short-term endeavors. ${ }^{56}$ Meanwhile, this culture failed to give employees incentives to avoid unprofitable deals in the long term. ${ }^{57}$ Moreover, because remuneration was so large in the short term, even the medium- or long-term failure of the bank was not a deterrent. ${ }^{58}$ Careers were expected to be short and remuneration was structured to reflect this expectation. ${ }^{59}$ As the governor of the Bank of England noted in 2009,

it was a form of compensation which rewarded gamblers if they won the gamble but there was no loss if you lost it. It is obvious that if you do that you will give incentives to people to gamble ... shareholders, boards, the financial press, all thought it was a great idea to reward people in this way. These bonuses were absolutely astronomic....

One of the things I found somewhat distressing about the lives of many people who worked in the City was that so many of them thought that the purpose of a bonus and compensation was to give them a chance to leave the City, to do something they really wanted to do, having built up enough money to give them the financial independence to do it. I think that is rather sad. ${ }^{60}$

Third, shareholders were not and still are not the major contributors of capital to U.K. banks, contributing only approximately $5 \%$ of the capital at the time of the crisis. ${ }^{61}$ The rest of the capital was made up of deposits and long- and short-term debt, mostly from other banks in addition to internally generated funding. ${ }^{62}$ Bank funding was and is dangerously short term in that depositors can withdraw their funding at any time. Thus, banks became increasingly reliant on short-term wholesale fund-

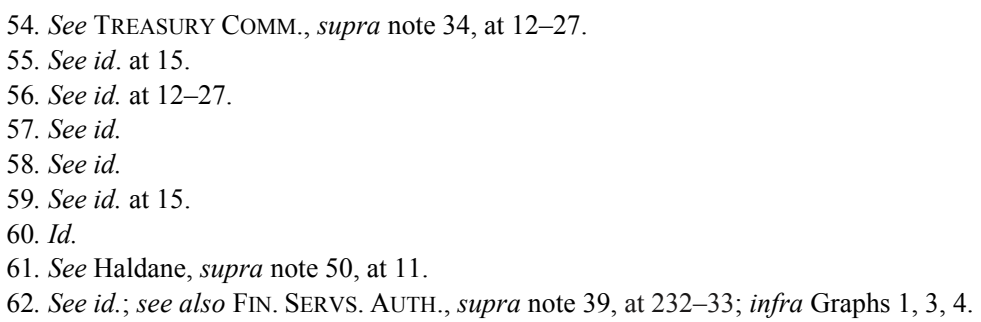


ing, largely from other banks, that by the early twenty-first century needed regular refinancing. ${ }^{63}$

Shareholders contributed minimal capital and had all the control rights, while the state carried all the residual liability. ${ }^{64}$ Bank shareholders who contributed a small percentage of a bank's total capital had exclusive control rights over the bank's total debt, revenue, plus equity capital, with the additional backstop of limited liability and a state guarantee. In essence, for a relatively small investment, shareholders could gamble with massive amounts of capital and achieve remarkable returns. This is not insignificant. As can be observed from Graph 1 below, leverage rates in U.K. banks reached historic highs by the early stages of the crisis in 2007 leaving them dangerously exposed.

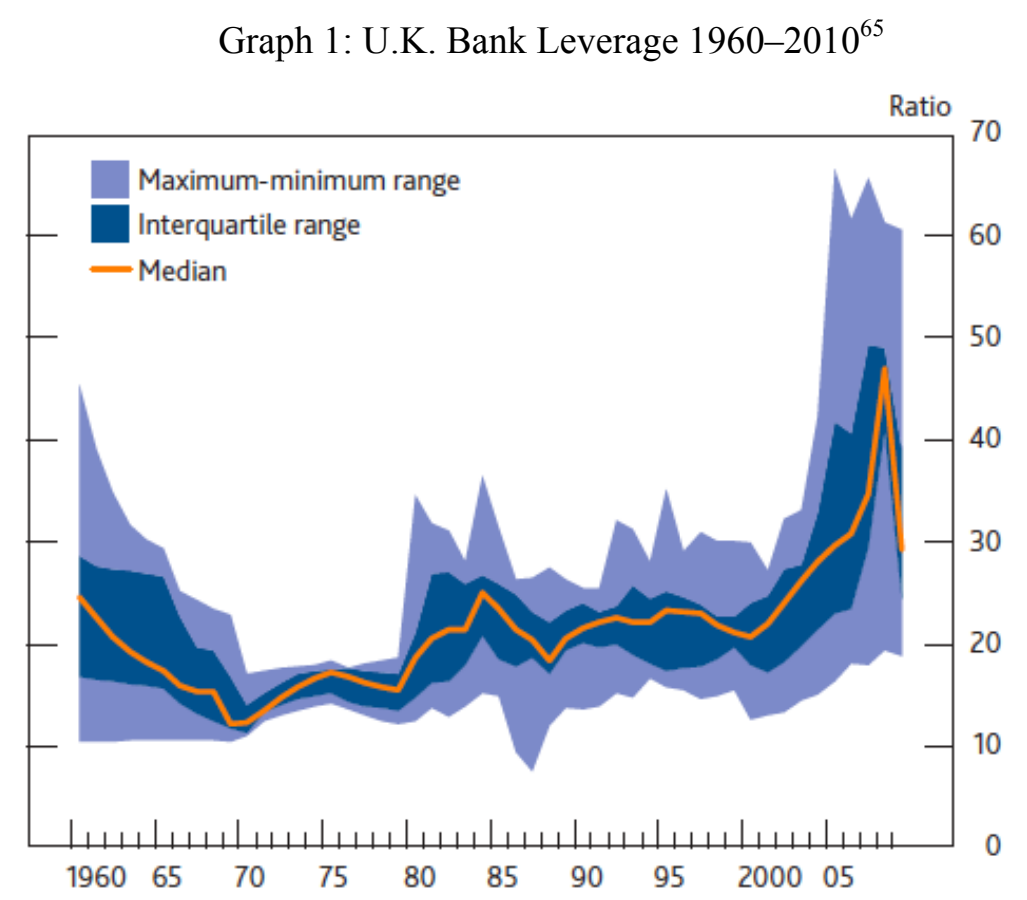

Shareholder returns on this leverage increase reached $30 \%$ at the peak of the twenty-first-century banking boom as the Merton model

63. See FIN. SERVS. AUTH., supra note 39, at 232-33.

64. See id.

65. Reproduced from BANK OF ENG., FinANCIAL StABILITY REPORT 52 chart 5.10 (2010), available at http://www.bankofengland.co.uk/publications/Documents/fsr/2010/fsrfull10 12.pdf. Graph 1 provides the ratio of assets to shareholder claims. For a PDF showing Graph 1 in color, see Archive, SEATtLE U. L. ReV., http://seattleuniversitylawreview.com/archive/ (last visited Feb. 23, 2013). 
reached its apotheosis, but with this boom came huge increased risk: a loss in the region of $3 \%$ to $5 \%$ of bank assets would wipe the bank out. ${ }^{66}$ Ironically, equity funding is probably much more important to banks than it is to other corporations because it has a stabilizing effect, which offsets the short-term nature of the majority of bank funding. ${ }^{67}$ But equity was minimal within the capital structure of U.K. banks in the decade running up to their failure and nationalization. ${ }^{68}$ Indeed, in the case of RBS, its "efficient" (thin) capital base was part of its leadership philosophy. ${ }^{69}$

The state assuming the banks' risk also allowed a huge subsidy in terms of capital cost to flow to the bank. Haldane noted:

[T] he implicit subsidy amounts to at least tens of billions of pounds per year, often stretching to three figures. For the global banks, the subsidy is worth at least hundreds of billions of dollars per year, on occasions four figures. These numbers are eye-popping. To give some context, they are a large chunk, and sometimes exceed, the measured valued-added of the financial sector to annual GDP.... The scale of subsidy suggests there is a considerable distance to travel before debtor discipline could be fully effective in checking risk-taking. ${ }^{70}$

The impact of providing the intended guarantees for depositors also had unintended effects on the TBTF banks, which could take enhanced risks on the basis of a state guarantee. ${ }^{71}$ As Graph 3 below illustrates, TBTF banks also extended the state guarantee internationally by lending and otherwise transacting with other international TBTF banks. Shareholders and taxpayers shouldered the liability for the debts of both domestic and international TBTF banks, effectively pushing long-term shareholders out of the banking system and increasing the presence and effect of speculative shareholders, who bet on getting out before the "doomsday machine" succeeded. ${ }^{72}$ As one can observe from Graph 2 below, speculative shareholders began to replace longer-term shareholders in 1998, as evidenced by the decrease in shareholding periods from over two years in

66. See Andrew Haldane, The Doom Loop, London Rev. Books, Feb. 23, 2012, at 21-22, available at $\mathrm{http}: / / \mathrm{www} .1 \mathrm{rb} . c 0 . u \mathrm{k} / \mathrm{v} 34 / \mathrm{n} 04 /$ andrew-haldane/the-doom-loop.

67. See INDEP. COMM'N ON BANKING, supra note 34, at 86.

68. See id.

69. See FIn. SERVS. AutH., supra note 39, at 232-33.

70. Haldane, supra note 50, at 11.

71. Id.; see supra Graph 1.

72. See TREASURY COMM., supra note 34 , at 59. 
1998 to barely quarterly holdings a decade later. This was a very significant change in the ownership and control of the U.K. banks. ${ }^{73}$

Graph 2: Shareholding Periods in Banks 1998-2011 ${ }^{74}$

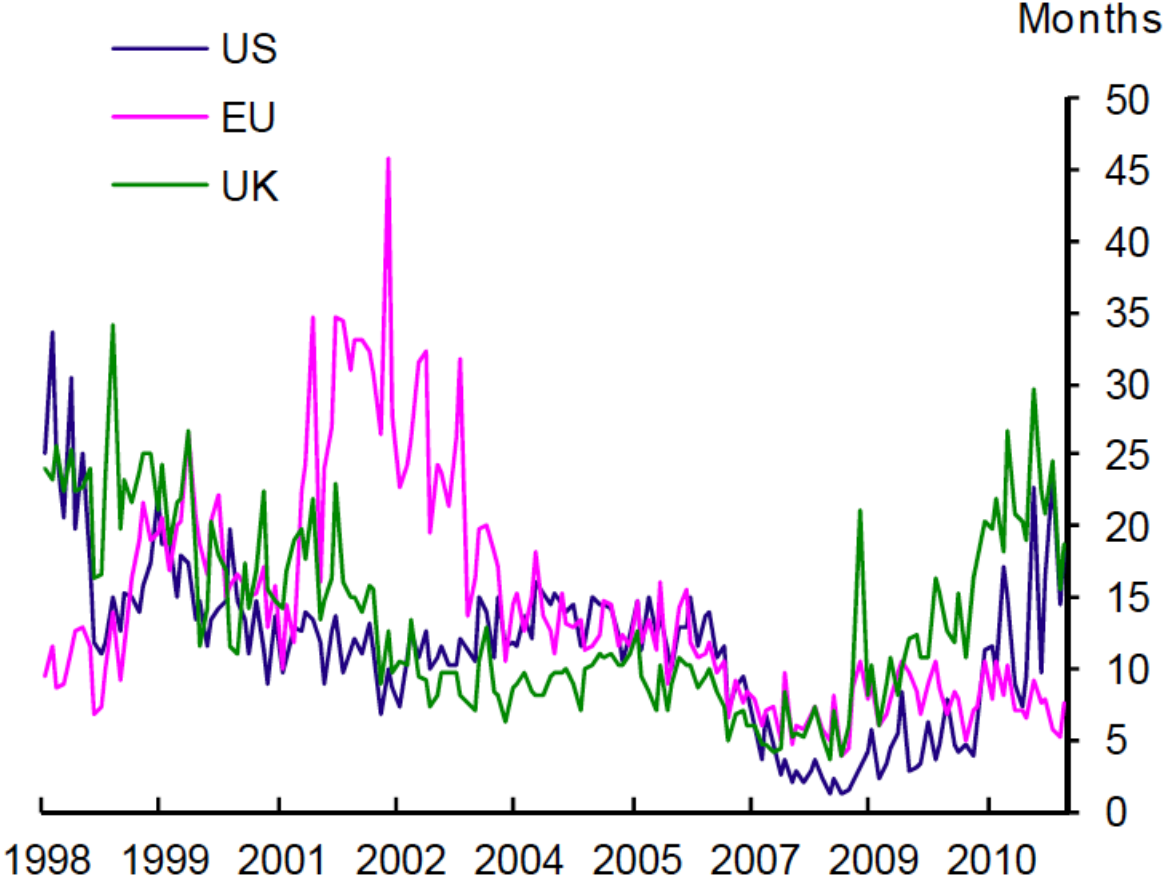

The increase in risk is linked with the ownership changes in the banks. The Investment Managers Association (IMA), whose members handle investments for most U.K. institutional investors, indicated to the Treasury Select Committee on Banking in 2008 that starting around 2005 "a number of active investment managers concluded that the strategies being followed by many banks were unsustainable, and that they should not keep their clients invested in the sector." ${ }^{, 75}$ Additionally, many longterm U.K. shareholders remaining after $2005^{76}$ began to see advantage in pursuing a trading strategy. ${ }^{77}$ Testifying for the Treasury's inquiry into

73. See infra Graph 2. This marks a significant change in the United States and the European Union as well.

74. Haldane, supra note 50, at 27. For a PDF showing Graph 2 in color, see Archive, SEATTLE U. L. REV., http://seattleuniversitylawreview.com/archive/ (last visited Feb. 23, 2013).

75. TREASURY COMM., supra note 34, at 59. This signal that all was not well was missed by the tripartite regulators in the United Kingdom.

76. See id. at 60.

77. See id. at 64. 
bank governance, both Peter Montagnon, Director for Investment Affairs at the Association of British Insurers (ABI), and David Pitt-Watson, Senior Adviser to Hermes Pension Fund Management, considered the precrisis boom in the presence of trader investors within the banks to be partly to blame for the ensuing crisis. ${ }^{78}$ Summing up his views, Mr PittWatson noted that "primarily a lot of us are trading shares rather than undertaking the task of being good owners of companies.",79

Not all shareholders pursued these strategies. A few long-term U.K. shareholders did attempt to engage with the banks on the high-risk management strategies, and others expected nonexecutive directors (NEDs) ${ }^{80}$ to do the monitoring for them. ${ }^{81}$ In both cases, the attempts at monitoring failed and the investors exited. ${ }^{82}$ At the same time that shareholding periods plummeted as illustrated by Graph 2 above, debt ratios were ramped up to historic highs as shown in Graph 1 above. From 2005, the vast majority of the remaining shareholders were only interested in ultra-shortterm returns, which had become the focus of shareholder activity in the banks, rather than long-term ownership. ${ }^{83}$ Shareholders sought increased short-term returns on equity, and management sought higher salaries guaranteed by hitting short-term targets. ${ }^{84}$ A comparison of Graph 1 and Graph 2 also shows that the vast increase in bank debt occurred when U.K. institutional investors began to disengage and sell their shares to speculative shareholders. As the Walker Review noted,

one element in the build-up to the recent crisis phase was the at least implicit calculation by some boards that led to the assumption of high leverage, possibly encouraged in this by shareholders, on the basis that the risk of serious loss in the longer-term was outweighed by the high returns on equity generated in the meantime. ${ }^{85}$

As a result, banks became the focus for activist short-term shareholders who targeted internal strategy change through remuneration incentives for the board and significant employees. ${ }^{86}$ Shareholder returns

78. See id.

79. Id.

80. NEDs are part-time outsiders who sit on the board to monitor and challenge the executive directors. Some are genuinely independent, but many have a connection to the company such as being a former executive or representing a shareholder. NEDs and their role in the banking crisis are discussed further below.

81. See TREASURY COMM., supra note 34, at 59-63.

82. See id.

83. See id. at $62-64$

84. See Haldane, supra note 50, at 11-12; see also THOMAS ClARKE, INTERNATIONAL CORPORATE GOVERNANCE: A COMPARATIVE APPROACH 149 (2007).

85. WALKER, supra note 3, at 136-37; see also Cheffins, supra note 2, at 40.

86. See Martin Hilb, Redesigning Corporate Governance: Lessons Learnt from the Global Financial Crisis, 15 J. MGMT. \& GovernanCE 533 (2011). 
then increased through extraordinary leverage levels, which increased shareholder, board, and employee returns while increasing risk. The increase in shareholder returns also fed the appetite for volatility of the traders, who bought on the ups and shorted the downs. ${ }^{87}$ And so from 1998, as increasingly influential short-term shareholders took control of the banks' strategic direction, managers and their remuneration incentives focused increasingly on the short term to increase returns from the "doomsday machine," which in turn increased the risks to long-term shareholders, other banks, and the state. ${ }^{88}$ Haldane described the process as follows:

What we have, then, is a set of mutually-reinforcing risk incentives. Investors shorten their horizons. They set ROE targets for management to boost their short-term stake. These targets in turn encourage short-term risk-taking behaviour. That benefits the short-term investor at the expense of the long-term, generating incentives to shorten further horizons. And so the myopia loop continues. ${ }^{89}$

Traders, short-term activist shareholders, and management reaped the rewards - at least for a time while traditional U.K. institutional investors sold their shares, further exacerbating the myopia loop. ${ }^{90}$

Fourth, while scholars recognized that long-term shareholders and the state bore the risk, what was not evident was the extent to which TBTF banks held interconnected risk as TBTF banks were significant funders and transaction-liability holders for each other. ${ }^{91}$ This interconnectedness of the exposure, as demonstrated by Graph 3 and Graph 4 below, emerged initially in the 2007 credit crunch and was fully revealed, both domestically and internationally, in the Lehman Brothers collapse in 2008. This interconnectedness increased the risk to long-term shareholders, the U.K. government, and other governments that had TBTF banks present in their jurisdictions. In other words, governments guaranteeing TBTF banks were significant liability holders not only for their domestic TBTF banks but for non-national TBTF banks as well. In short, governments as residual liability holders were seriously unrepresented in the internal governance and risk planning of TBTF banks.

87. See Haldane, supra note 50 , at $11-12$.

88. See FIN. SERvS. AUTH., supra note 39, at 225 (discussing the incentives for senior management to increase risk, which was not just a U.K. phenomenon); see also David H. Erkens, Mingyi Hung \& Pedro P. Matos, Corporate Governance in the 2007-2008 Financial Crisis: Evidence from Financial Institutions Worldwide, 18 J. CORP. FIN. 389 (2012).

89. Haldane, supra note 50, at 12.

90. See WALKER, supra note 3, at 27.

91. See INDEP. COMM'N ON BANKING, supra note 34, at 127-28. 
Graph 3: The Growth of International Exposure: Consolidated Foreign Claims of U.K.-Headquartered Banks ${ }^{92}$

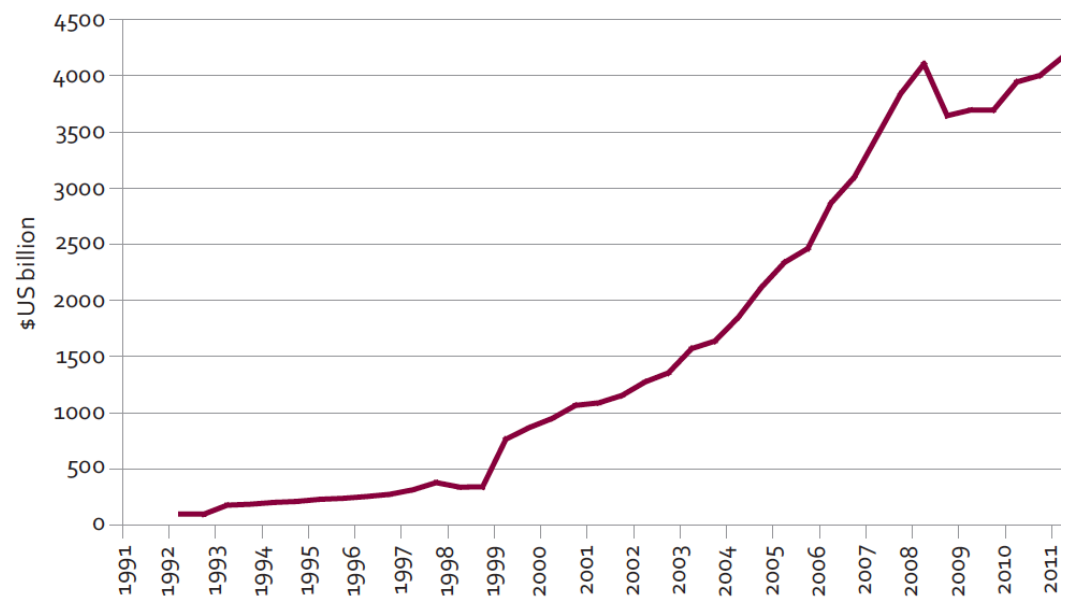

Graph 4: Bank Loans to Sectors of the U.K. Economy ${ }^{93}$

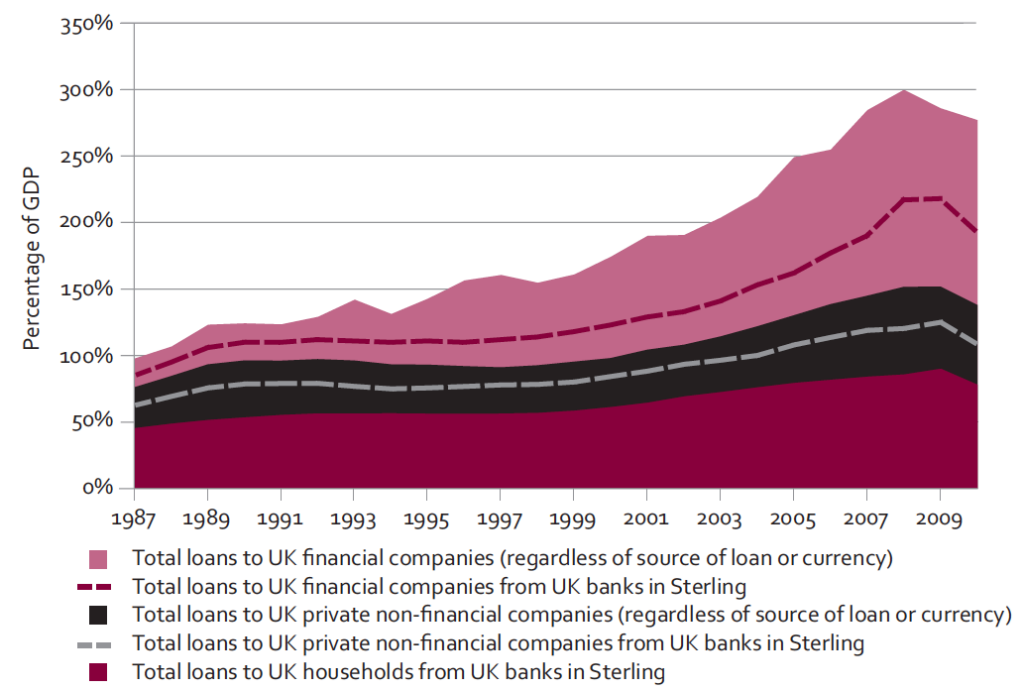

By the time of the financial crisis, U.K. banks had become focused on high-risk, high-return activities encouraged by short-term sharehold-

92. Id.

93. Id. at 51. For a PDF showing Graph 4 in color, see Archive, SEATtLE U. L. REV., http://seattleuniversitylawreview.com/archive/ (last visited Feb. 23, 2013). 
ers and ably assisted by the NEDs. ${ }^{94}$ The Treasury Select Committee on Banking expounded on the role of the NED in the crisis:

The financial crisis has exposed serious flaws and shortcomings in the system of non-executive oversight of bank executives and senior management in the banking sector. In particular, the evidence shows that many non-executive directors - in many cases eminent and highly-regarded individuals with no shortage of experience in the business and banking worlds - failed to act as an effective check on, and challenge to, executive managers. Too often non-executive directors in the banking sector have operated as members of a "cosy club" rather than viewing their role as being that of providing effective checks and balances on executive members of boards. ${ }^{95}$

The subprime crisis was the trigger for the wider financial crisis, but the underlying cause was an extraordinarily dysfunctional corporate governance structure operating throughout the U.K. banking sector by 2007 . The entire edifice of the U.K. corporate governance systemshareholders, NEDs, management, self-regulation, and government oversight — failed in the financial crisis. Picking up the pieces is no easy task.

\section{The Reform Process}

In an attempt to address these corporate governance failings, the U.K. Treasury in February 2009 asked Sir David Walker, a senior adviser to the U.S. investment bank Morgan Stanley and a former director of the Bank of England, "to review corporate governance in UK banks in the light of the experience of critical loss and failure throughout the banking system." Sir David's connection with Morgan Stanley created significant concern that his report would not provide the governance shake-up that the banking industry needed. ${ }^{97}$ As the Treasury Select Committee on Banking noted,

his experience and professional background means that he undoubtedly fits the description of a "City grandee." However, we are not convinced that Sir David's background and close links with the City

94. See TREASURY COMM., supra note 34, at 62-64. Long-term shareholders do seem to exert a restraining influence on remuneration. See generally Min Dong \& Aydin Ozkan, Institutional Investors and Director Pay: An Empirical Study of UK Companies, 18 J. Multinat'L Fin. MgmT. 16 (2008).

95. TREASURY COMM., supra note 34, at 55.

96. WALKER, supra note 3, at 6. There were also two other reviews on the financial crisis. See FIN. SERVS. AUTH., supra note 34; see also INDEP. COMM'N ON BANKING, supra note 34.

97. See TREASURY COMM., supra note 34 , at 58. 
of London make him the ideal person to take on the task of reviewing corporate governance arrangements in the banking sector. ${ }^{98}$

Expectations were low, and to that extent they were largely met. ${ }^{99}$ Sir David concluded: (1) executives and nonexecutives on the bank boards failed to understand the scale of the risks their organizations had taken; (2) shareholders in banks failed to curb reckless gambling; and (3) the remuneration system encouraged bank employees to speculate imprudently. ${ }^{100}$ He proposed a number of solutions for the financial sector, including monitoring internal risk, requiring NEDs to devote more time to their role, and introducing deferred performance-related pay. In addition, he made a number of suggestions: that NEDs should be vetted by the FSA; that remuneration committees deal with all "high end" employees, not just the board; that these high end employee salaries be disclosed along with board salaries; that the board and FSA monitor shareholder sales to understand the reasons for sale; and crucially, that shareholders abide by a stewardship code committing them on a comply-or-explain basis to longer-term engagement with the banks. ${ }^{101}$ Stewardship required shareholders to have clear public policies on monitoring, voting, intervention, and collective action. ${ }^{102}$

Judged by the standards of the previous corporate governance reports, such as the Cadbury, Greenbury, and Hample reports, ${ }^{103}$ Sir David's report was similarly carefully measured in its response. Unfortunately, he was not reporting at a "normal" time or in a normal crisis situation, and given the public appetite for significant governance reform in the banks responsible for triggering the financial crisis, "measured" feedback was never going to be received well. Indeed, the combination of suspicion of a conflict of interest related to his position with Morgan Stanley, and the lack of any suggestion of significant reforms meant the report was met with great disappointment. ${ }^{104}$ Specifically, many of the reforms he suggested were already present in U.K. banks before the cri-

98. Id.

99. See Katie Allen, Campaigners Blast Walker Report on Banks, GUARDIAN (Nov. 26, 2009), http:/www.guardian.co.uk/business/2009/nov/26/walker-report-attacked-by-campaigners.

100. See generally WALKER, supra note 3.

101. Id.

102. See generally FIN. REPORTING COUNCIL, THE UK STEWARDShIP CODE (July 2010), available at http://www.frc.org.uk/FRC-Documents/FRC/The-UK-Stewardship-Code.aspx.

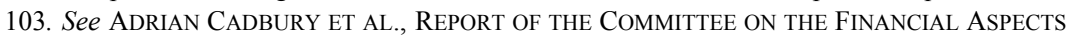
OF CORPORATE GOVERNANCE (1992), available at http://www.ecgi.org/codes/documents/cad bury.pdf; see also SIR RICHARD GREENBURY ET AL., DIRECTORS' REMUNERATION (1995), available at http://www.ecgi.org/codes/documents/greenbury.pdf; RONNIE HAMPEL ET AL., COMM. ON CORPORATE GOVERNANCE, FINAL REPORT (1998), available at http://www.ecgi.org/codes/docu ments/hampel.pdf.

104. See Allen, supra note 99. 
sis. For example, Northern Rock had a risk committee, but the committee failed to stop the bank's collapse. ${ }^{105}$ Under the U.K. Corporate Governance Code, bank remuneration committees already had technical responsibility for general levels of employee pay, and this had little effect on risk or pay inflation. ${ }^{106}$ Disclosure of executive pay in the 1995 report of the Greenbury committee had also been one of the significant drivers of increased executive pay, so enhanced disclosure seemed unlikely to help solve pay issues in the banks. ${ }^{107}$ The key plank of the Walker Review, in terms of future reform of shareholder behavior, was the concept of stewardship, which translated into a stewardship code that most institutional investors already complied with. ${ }^{108}$

Ultimately, the report's greatest failing was its general portrayal of the shareholders as passive "owners" who did not exercise proper oversight rather than as active owners who were engaged with a dangerous short-term agenda. ${ }^{109}$ In the Walker Review reforms, shareholders are passive rather than active, even though at points in the review he accepts that some shareholders may have been actively conspiring with boards to take high-danger, short-term risks. ${ }^{110}$ The Walker Review had the effect of moving the agenda away from examining the key active role shareholders had in bringing about the crisis and toward a much more benign starting point of shareholder passivity that could be solved by moving to long-term stewardship of the banks. ${ }^{111}$ According to this standpoint, shareholders are sure to be good if we show them the way. Although not intended, Sir David, who subsequently went on to become the chairman of Barclays bank, left a strong impression that something more needed to

105. See generally Treasury Comm., THE Run ON tHe Rock, 2007-8, H.C. 56-I, at 18-19 (U.K.), available at http://www.publications.parliament.uk/pa/cm200708/cmselect/cmtreasy/56/ 56i.pdf.

106. Fin. RePorting Council, UK Corporate Governance Code, § D1 (2012), available at http://www.frc.org.uk/Our-Work/Codes-Standards/Corporate-governance/UK-Corporate-Gover nance-Code.aspx; see also TUC Response to the Walker Review of Bank Governance, TRADE UNION CONG. 18 (Sept. 2009), http://www.tuc.org.uk/extras/walkerreviewsubmission.pdf.

107. See Jennifer G. Hill \& Charles M. Yablon, Corporate Governance and Executive Remuneration: Rediscovering Managerial Positional Conflict, 25 U. NEW S. WALES L. J. 294 (2002); Tracy Corrigan, Walker Review: Disclosure Will Push Bankers' Pay Up, TelegraPh (Nov. 26, 2009), http://blogs.telegraph.co.uk/finance/tracycorrigan/100002250/walker-reviews-forced-disclos ure-will-push-pay-up-not-down/.

108. See Cheffins, supra note 2, at 21-22.

109. See WALKER, supra note 3, at 69-72.

110. See id. at 136-37.

111. For a good example of this, see Ruth Sutherland, A Plea to Sir David: Save Our Schools, Jobs and Pensions from Britain's Timid Investors, GUARDIAN (July 11, 2009), http://www.guardian.co.uk/business/2009/jul/12/david-walker-banking-regulation. 
be done to address the problems of short-termism within the British banking industry. ${ }^{12}$

In 2010, the incoming Liberal-Conservative coalition government took the baton by launching a flurry of initiatives on post-crisis corporate governance in British companies. ${ }^{113}$ The most important of these consultations, apart from the 2012 Department for Business Innovation and Skills (BIS) proposal to introduce mandatory "say on pay," 114 was the Kay Review of U.K. Equity Markets and Long-Term Decision Making (Kay Review). ${ }^{115}$ Professor John Kay was tasked to examine investment in U.K. equity markets and its impact on the long-term performance and governance of U.K.-quoted companies. ${ }^{116}$ In February 2012, Kay and his colleagues produced the interim review, which provided a wide range of evidence that British companies were subject to damaging short-term pressures from equity markets. It then went on to set out ideas for correcting this problem: changes to long-term-focused directors' duties; dual-class voting and tax incentives to encourage long-term shareholding; and reduced financial disclosure to encourage managers to plan for the longer term. ${ }^{117}$ The final report appeared in July 2012. Of its suggested interim solutions, the only significant one remaining in the final report concerned removing quarterly disclosure. The report's other main focus, in terms of solving the short-termism problem, was to target the investment chain. ${ }^{118}$ This would mean focusing on encouraging trust, providing long-term incentives for asset managers, and introducing fiduciary standards of care for those in the investment chain while also encouraging good practice focused on long-term investing. ${ }^{119}$ On remuneration for

112. James Quinn, Sir David Walker to Chair Barclays: Profile, TelegraPh (Aug. 9, 2012), http://www.telegraph.co.uk/finance/newsbysector/banksandfinance/9465247/Sir-David-Walker-tochair-Barclays-profile.html.

113. See Directors' Pay: Consultation on Enhanced Shareholder Voting Rights, DEP'T FOR Bus. INNOVATION \& SKILLS (Mar. 2012), http://www.bis.gov.uk/Consultations/executive-payshareholder-voting-rights?cat=closedwithresponse [hereinafter Directors' Pay]; see also A LongTerm Focus for Corporate Britain: A Call for Evidence, DEP'T. FOR BUS. INNOVATION \& SKILLS (Oct. 2010), http://www.bis.gov.uk/Consultations/a-long-term-focus-for-corporate-britain; Women on Boards, DEP'T. FOR BUS. INNOVATION \& SKILLS (Oct. 2010), http://www.bis.gov.uk/Consulta tions/women-on-boards.

114. Directors' Pay, supra note 113; see also Directors' Pay: Revised Remuneration Reporting Regulations, DEP'T. FOR BUS. INNOVATION \& SKILLS (June 2012), http://www.bis.gov.uk/Cons ultations/directors-pay-revised-remuneration-reporting-regulations?cat=open.

115. See KAY, FINAL REPORT, supra note 3.

116. See id.

117. John Kay, The Kay Review of UK EQuity Markets and Long-Term Decision MAKING: INTERIM REPORT (2012), available at http://www.bis.gov.uk/assets/biscore/businesslaw/docs/k/12-631-kay-review-of-equity-markets-interim-report.pdf [hereinafter KAY, INTERIM REPORT].

118. See generally KAY, FINAL REPORT, supra note 3, at 44-56, 65-69.

119. See id. 
executives, the review refreshingly recommended ultra-long-term share incentives to ensure a focus on the very long term. ${ }^{120}$ Again, these are significant recommendations, but where shareholders were concerned the final report focused on encouraging a form of enhanced shareholder stewardship based on trust, respect, engagement, and understanding, which should not only include engagement with matters of corporate governance but strategic issues as well. ${ }^{121}$

The Kay Review is a very different beast when compared to Sir David's report. The Kay Review looked at the whole of the U.K. investment market and thus necessarily had a much wider focus. In particular, its recommendations on remuneration and disclosure distortions to board discretion mark an important recognition of the issues that affect board discretion, which will be discussed in the next Part. Still, the Kay Review's ideas on enhanced stewardship and shareholder coordination strongly correspond with Sir David's view of stewardship and indeed surpass it in terms of its expectation of turning passivity into engagement by extending stewardship into strategic issues as well. The assumption of shareholder passivity, as this Article argues, perpetuates a good but passive shareholder myth when a form of bad shareholder activism is the existing and coming problem. Again, although the Kay Review recognized the short-term activities of shareholders in the banks, ${ }^{122}$ it appears in general that the lesson we did not learn from the U.K. bank collapses, was that a cocktail of shareholder influence and a lack of independent board power is a very dangerous thing. We turn in the next Part to consider why U.K. boards generally are uniquely vulnerable to shareholder activism.

\section{VULNERABLE BOARDS}

While it is hard to feel sympathy for excessively remunerated directors who came close to bringing down the world's financial system, there is a very important lesson to be learned from the crisis. This crisis revealed just how vulnerable U.K. boards are to active shareholders. This lesson is particularly important because a board's vulnerability makes the direction of travel, in terms of shareholder empowerment in U.K. corporate governance reform, highly questionable. ${ }^{123}$ In the United Kingdom, the constitutional heart of the corporation regulating the power structure

120. See id. at $77-81$.

121. See id. at $44-45$.

122. See id. at 20.

123. As we have considered in Part II, above, the final reports of both the Walker and Kay Review focused on an activist stewardship solution. See generally WALKER, supra note 3; see also KAY, FINAL REPORT, supra note 3. 
of the company is mostly left to those forming the company to decide upon. The organs of the standard company - the board and the general meeting - are provided as a default provision for those forming the company. ${ }^{124}$ Historically, most individuals have used the default standard articles of association provided by the Companies Acts. ${ }^{125}$ Whether or not those forming the company use the default rules creating the board and general meeting, the internal rules provided by the original framers become the rules of the company by which the shareholders and directors are bound unless a special majority amends the rules. ${ }^{126}$

As such, the core rules defining the relationship between the board and the shareholders are an internal and private contractual matter, not a matter for formal company law. But when there is a contractual dispute about the enforcement or abuse of the rules, a court may have to determine the outcome. ${ }^{127}$ It is in the various determinations of the courts that we find what is essentially a special category of contract law, where the unusual nature of this contract - it concerns the interests of an artificial entity, it can be amended without the consent of all the parties, and it automatically binds new parties to it - has created significant complexity for companies, judges, shareholders, and directors. ${ }^{128}$ The way the judiciary has dealt with directors' discretion and the duty to act in the interests of the company illustrates both the complexity of the issue and the direction of travel for corporate accountability. We consider each in turn.

\section{A. Directors' Discretion}

The most important function of the articles of association is to allocate the power of the company between the board and the general meeting. ${ }^{129}$ This allocation of power is found in articles 3 and 4 of the model default articles (public and private) and states:

124. See Alan Dignam \& John Lowry, Company LaW 132-53 (7th ed. 2012).

125. See generally The Companies (Model Articles) Regulations 2008, COMPANIES HousE (Dec. 16, 2008), available at http://www.companieshouse.gov.uk/about/modelArticles/modelArtic les.shtml.

126. Paul Davies \& L.C.B. Gower, Gower and Davies: Principles of Modern COMPANY LAW 62-65 (8th ed. 2007).

127. Some statutory provisions such as section 168 of the Companies Act 2006 (which provides the power to remove directors with a simple majority) are aimed at enhancing the private contractual bargain.

128. The issue of the status of the articles of association itself remains a matter of some controversy. See DIGNAM \& LOWRY, supra note 124.

129. See id. at 143-46. 


\section{Directors' general authority}

3 Subject to the articles, the directors are responsible for the management of the company's business, for which purpose they may exercise all the powers of the company.

\section{Shareholders' (Members) reserve power}

4(1) The shareholders (Members) may, by special resolution, direct the directors to take, or refrain from taking, specified action.

(2) No such special resolution invalidates anything which the directors have done before the passing of the resolution. ${ }^{130}$

Although that power is subject to the qualifications of the articles of the company and any special resolutions, the board is appointed the primary power-wielding organ of the company under article 3 .

The extent of this delegation of power to the directors has been the subject of much judicial deliberation over time. The key question in the case law has been whether the delegation of general authority to run the company to the board creates a substantially independent discretion for the directors. In short, within their general management power could the board take a course of action the shareholders disagreed with? In Howard Smith Ltd. v. Ampol Petroleum Ltd., Lord Wilberforce summed up the position in the case law:

The constitution of a limited company normally provides for directors, with powers of management, and shareholders, with defined voting powers having power to appoint the directors, and to take, in general meeting, by majority vote, decisions on matters not reserved for management... it is established that directors, within their management powers, may take decisions against the wishes of the majority of shareholders, and indeed that the majority of shareholders cannot control them in the exercise of these powers while they remain in office. ${ }^{131}$

This discretion is of course tempered by the limits in article 4 above and, perhaps more significantly, the fact that section 168 of the Companies Act 2006 allows a simple majority of the shareholders to remove the board. ${ }^{132}$ In a practical sense, directors must tread carefully on antagonistic issues despite their constitutional power. Nonetheless, in a constitutional sense, the board once empowered has in theory a substantially in-

130. Companies Act 2006-Model Articles, COMPANIES House 4-5 (Dec. 16, 2008), available at http://www.companieshouse.gov.uk/about/modelArticles/modelArticles.shtml. Public and private companies in the U.K. have separate articles of association. Both forms share the same articles on directors' authority.

131. [1974] A.C. 821 (P.C.) 837 (appeal taken from New South Wales).

132. See Companies Act, 2006, c. 46, § 168 (U.K.) 
dependent discretion to run the company as it sees fit. ${ }^{133}$ The danger in such an independent power is that the management may utilize its discretion to benefit itself rather than the company. In response to this danger, the judiciary developed a range of special duties for directors to set the limits of their authorized power.

\section{B. Directors' Duties}

Although developed by the judiciary over two centuries, the general duties of directors are now codified in the Companies Act of 2006 as follows: (1) the duty to act within their powers; (2) the duty to promote the success of the company; (3) the duty to exercise independent judgement; (4) the duty to exercise reasonable skill and diligence; (5) the duty to avoid conflicts of interest; and (6) a duty not to accept benefits from third parties. ${ }^{134}$ Section 170 specifically states that these duties are owed to the company and derived from the previous common law and equitable duties, and that they must be interpreted and applied in the same way as those duties.

In developing these duties, the U.K. judiciary found that maintaining a balance between the directors' discretion and accountability to shareholders is not a straightforward task. The judiciary carefully crafted decisions on the question of who the directors owe their duties to when they exercise their powers. In one sense, this is easy to answer: the duties are owed to the company. This would seem to enhance the independence of the directors given that the company is a separate legal entity-a notion the U.K. judiciary is deeply attached to ${ }^{135}$ - and directors have the primary governance role in the company. ${ }^{136}$ In reality, this does not take us a long way: when one tries to identify the interests of the company, we encounter a problem.

How do we identify the interests of the "company"? Does the company have its own independent interests, or is it made up of its differing constituencies such as shareholders, employees, creditors, and the community? Does one constituency dominate in terms of accountability? The

133. The board is also given, by virtue of article 30 (for private companies) and article 70 (for public companies) the power to decide whether to distribute any surplus profits to the shareholders in the form of dividends. Although technically the general meeting declares the dividend, it cannot do so unless the board recommends a dividend. This is another very important independent power exercised by the board. The default rule of the model articles thus similarly recognizes that the board needs a significant amount of discretion regarding how to allocate any surplus profit generated by the company's activities. The shareholders may want the profits to be distributed to them as dividends, but the directors may wish to reinvest the profits to develop the long-term future of the business. The directors are given that discretion in the articles.

134. See Companies Act, 2006, c. 46, $\S 171-176$ (U.K.).

135. See, e.g., Adams v. Cape Industries PLC, [1990] Ch. 433 (A.C.).

136. See discussion supra Part III.A ("Directors Discretion"). 
issue is of course strongly resonant of the famous debate between Adolf Berle and Merrick Dodd, played out in the pages of the Harvard and Chicago Law Reviews in the 1930s. Dodd advocated a broad accountability model in which the board was a key gatekeeper while Berle advocated a focused shareholder model. ${ }^{137}$ The U.K. judiciary has tried to split the Dodd-Berle difference to maintain discretion for directors, as in Howard Smith, ${ }^{138}$ while ensuring a complex form of shareholder accountability through a duty to the company. For example, in Greenhalgh v. Arderne Cinemas Ltd., the court took the view that "the phrase "the company as a whole' does not ... mean the company as a commercial entity, distinct from the corporators: it means the corporators as a general body." ${ }^{\prime 139}$ In Multinational Gas \& Petrochemical Co. v. Multinational Gas \& Petrochemical Services, the court stated, "Indeed, so long as the company is solvent the shareholders are in substance the company."

A strict adherence to the idea of shareholders "being" the company created tension between the core principle that the company is separate from the shareholders and the principle of judicial consideration of the extent to which directors have an independent power conferred upon them in the articles. How can shareholders be both separate from the company and the substance of the company at the same time? If they are the company, then liability should flow to them. If directors are compelled to act in the interest of the shareholders, how can they exercise an independent decisionmaking power conferred under the articles that might sometimes legitimately require them to act against the wishes of the current shareholders? Would they not be compelled to always consult the shareholders and act on command, lest they breach their duties? In that case, what exactly are the directors for if no real delegation of power takes place? In solving this puzzle, the judiciary has emphasized the director's role in "interpreting" the interests of the company. Lord Justice Bowen addressed this point in an early classic case when he stated:

A railway company, or the directors of the company, might send down all the porters at a railway station to have tea in the country at the expense of the company. Why should they not? It is for the di-

137. See A.A. Berle, Jr., Corporate Powers as Powers in Trust, 44 HaRv. L. REV. 1049 (1931); see also A.A. Berle, Jr., For Whom Are Corporate Managers Trustees: A Note, 45 HARV. L. REV. 1365 (1932); E. Merrick Dodd, Jr., For Whom Are Corporate Managers Trustees?, 45 HARV. L. REV. 1145 (1932); E. Merrick Dodd, Jr., Is Effective Enforcement of the Fiduciary Duties of Corporate Managers Practicable?, 2 U. CHI. L. REV. 194 (1935).

138. See Howard Smith Ltd. v. Ampol Petroleum Ltd., [1974] A.C. 821 (P.C.) 838 (appeal taken from New South Wales).

139. Greenhalgh v. Arderne Cinemas Ltd., [1951] Ch. 286 (C.A.) 291.

140. Multinational Gas \& Petrochemical Co. v. Multinational Gas \& Petrochemical Servs., [1983] Ch. 258 (A.C.) 288 (Eng.). 
rectors to judge, provided it is a matter which is reasonably incidental to the carrying on of the business of the company; and a company which always treated its employees with draconian severity, and never allowed them a single inch more than the letter of the bond, would soon find itself deserted - at all events, unless labour was very much more easy to obtain in the market than it often is. The law does not say that there are to be no cakes and ale, but there are to be no cakes and ale except such as are required for the benefit of the company ... ${ }^{141}$

Similarly, in Evans v. Brunner Mond \& Co., Justice Eve held that the directors of a chemical company could make donations to universities for scientific research despite there being no immediate gain to the company. ${ }^{142}$ The ostensible grounds for allowing this was that profit (albeit intangible or long term) inures to the company eventually. Most importantly, the 1954 report of the second Savoy Hotel investigation considered a situation where the directors of the Savoy Hotel group had attempted to defeat a hostile takeover by removing an important asset from the company. ${ }^{143}$ The report produced the proposition that while the duty was indeed ultimately owed to the shareholders, the duty was not confined to the existing body of shareholders, and future shareholders must also be considered. ${ }^{144}$ Subsequently, the judiciary repeated this formula as representing the appropriate balance. ${ }^{145}$

Accordingly, directors could, in certain circumstances, depart from adherence to the wishes of current shareholders on the basis of the longer-term interests of the shareholders or a balance of the two. ${ }^{146}$ While still a shareholder-accountability solution in the manner of Berle, this approach provided a key avenue to maintain directors' discretion to act in the longer term and, to a certain extent, solve the problem of the company being separate from the shareholders. ${ }^{147}$

The formulation was a necessary recognition of the need for boards to make legitimate difficult decisions within their delegated power. They

141. Hutton v. West Cork Ry. Co., [1883] 23 Ch.D. 654, 672-73.

142. See Evans v. Brunner Mond \& Co., [1921] 1 Ch. 359.

143. See E. Milner Holland, Gr. Brit. Bd. of Trade, The Savoy Hotel Ltd. and the Berkeley Hotel Co. LtD.: Report of AN InVestigation Under SeCtion 165(6) OF the COMPANIES ACT 1948 (1954).

144. See id.

145. See Gaiman v. Nat'l Assoc. for Mental Health, [1971] Ch. 317, 330; Brady v. Brady, [1987] 3 B.C.C. 535; Dawson Int'l PLC v. Coats Paton PLC (No.1), [1988] S.L.T. 854; see also Surman v. HM Advocate, [1988] S.C.L.R. 371; EILIS FERRAN, COMPANY LAW AND CORPORATE FINANCE 126 (1999).

146. See Re BSB Holdings (No 2), [1996] 1 BCLC 155, 251; Gaiman, [1971] Ch. 317; see also Lyndon MacCann, Directors Fiduciary Duties: Part Two, 9 IRISH L. TIMES 104 (1991).

147. See FERRAN, supra note 145, at 126. 
operate as a type of agent, and as such, the judiciary has constructed duties owed to the company, which they have in turn construed as being owed to the shareholders. This construction is not as straightforward as it seems because of two reasons: (1) the presence of the corporation between the shareholders and the directors; and (2) the necessity of construing a delegation of power broadly enough for it to allow difficult but legitimate management decisions that may affect current shareholders. But a certain mystery remains within U.K. corporate law: Why is there no definitive case that ultimately determines a director's obligations when faced with a difference between his or her honest view as to the future strategic direction of the company and the shareholders' differing views?

After the 1960s, relatively little case law exists addressing the tension between board independence and the duty to act in the interests of the company. In the rare general cases where they do have to make a decision on the nature of board discretion versus obligations to shareholders, ${ }^{148}$ the judges in question seem to do their best to avoid making a definitive decision on the issue.

On specific aspects of directors' powers, outside their general discretion, there are some significant cases. In Hogg v. Cramphorn Ltd., the directors of a company used their specific power to issue shares to the trustees of the company's employee-welfare scheme. ${ }^{149}$ This action, if valid, would have meant that a hostile bid for the company could not succeed. The court held that the directors had been given the power to issue shares specifically to raise capital for the company and not to defeat a takeover. ${ }^{150}$ The issue of the shares was invalid. ${ }^{151}$

In Howard Smith (discussed above), a similar set of facts were involved whereby the court, after emphasizing the independent bona fide management powers of the board, found that the exercise of power-in this case to issue shares to defeat a takeover-was not a valid use of that specifically awarded power. The power had been given to raise capital, and the court determined that it must be exercised only for that primary purpose.

These two cases taken together generally stand for the proposition that where the shareholders confer a specific power for a specific purpose, the power must only be used for that proper purpose. Indeed, as was discussed earlier, the Howard Smith case is also clear that with re-

148. See, e.g., Re Welfab Engineers Ltd., [1990] BCLC 833; see also BSB Holdings, [1996] 1 BCLC at 251.

149. See Hogg v. Cramphorn Ltd., [1967] Ch. 254.

150. See id.

151. See id. 
gard to the board's general discretion to run the company a substantial independent discretion exists. However, the outcome of these two cases hinges not on the extent of the general discretion but on a power separated from the general discretion of the board that is usually conferred specifically by shareholders for a limited time. ${ }^{152}$

Even within the interpretation of this discrete power, there is some dissent from this strict proper purpose doctrine. In Cayne v. Global Natural Resources $P L C$, Vice-Chancellor Megarry was clear that the properpurpose rule was not rigid, and these cases did not always prevent directors from utilizing their power for an ulterior purpose that was in the interests of the company. ${ }^{153}$ More recently, Justice Hart in Criterion Properties PLC v. Stratford UK Properties LLC interpreted the board's powers in a takeover in a way that made the board both strong and independent. ${ }^{154}$ If the board takes the view that "economic damage" will occur to the company as a result of a takeover, the exercise of its powers to prevent the takeover would be warranted. ${ }^{155}$

These cases in general emphasize the validity of the independent authority of the board. However, some view the exercise of a specific authority given by the shareholders for a specific purpose such as issuing shares to be invalid if tainted by an ulterior motive. Others such as the Criterion Properties and Cayne cases portray the ulterior motive as a central but legitimate driver of the exercise of board power, as long as harm might occur to the company if it does not act. ${ }^{156}$ So, could shares be issued to thwart a takeover? Well, maybe - that's probably as close as we will get to an answer given the state of judicial interpretation on the matter. Similarly, the issue of whether the general independent discretion of a board could encompass a frustrating action in a takeover brings us back to issues of subtle judicial interpretation and balance.

In Heron International Ltd. v. Lord Grade, the court put forward a two-stage duty test as to the board's discretion in a takeover. ${ }^{157}$ First, the directors need to decide if the takeover is in the interests of the company. Second, if they decide it is in the interest of the company, then "[w]here the directors must only decide between rival bidders, the interests of the

152. See DAVIES \& Gower, supra note 126, at 833-34; see also Carsten Gerner-Beuerle et al., Is the Board Neutrality Rule Trivial? Amnesia About Corporate Law in European Takeover Regulation 13 (London Sch. of Econ. Legal Studies, Working Paper No. 3, 2011), available at http://ssrn.com/abstract=1799291.

153. See Cayne v. Global Natural Res. PLC (unreported decision of Sir Robert Megarry, V.C., Aug. 12, 1982), aff'd on other grounds, [1984] 1 All E.R. 225.

154. Criterion Props. PLC v. Stratford UK Props. LLC, [2002] EWHC 496 (Ch.).

155. See id.

156. See id.; see also cases cited supra note 153.

157. See Heron Int'l Ltd. v. Lord Grade, [1983] BCLC 244. 
company must be the interests of the current shareholders." ${ }^{\text {"158 }}$ On the facts of the case, it was not necessary to consider what would happen if the directors decided it was not in the interests of the company. ${ }^{159}$ Nevertheless, the first part of the test suggests a substantial independent decisionmaking role for the board on these matters. Similarly, Lord Cullen in Dawson International PLC v. Coats Patons PLC stated as follows:

I think it is important to emphasise that what I am being asked to consider is the alleged fiduciary duty of directors to current shareholders as sellers of their shares. This must not be confused with their duty to consider the interests of shareholders in the discharge of their duty to the company. What is in the interests of current shareholders as sellers of their shares may not necessarily coincide with what is in the interests of the company. The creation of parallel duties could lead to conflict. Directors have but one master, the company. ${ }^{160}$

While Lord Cullen's view places the company centrally in the deliberations of the directors when they exercise their general management powers, his view also has the effect of bringing us full circle back to the finely balanced Savoy proposition. ${ }^{161}$

Still, despite the balance seemingly achieved in the report of the Savoy Hotel investigation, the duty to act in the interest of the company - translated as allowing directors to take a longer-term view to current shareholders - has remained a weak influence in the area. ${ }^{162}$ Something else happened in the 1960s that has since exerted a much stronger gravitational pull than the judiciary on the balance between management independence and shareholder accountability. As a result, we have a few cases that U.K. corporate lawyers can argue about, but no definitive case law has arisen. The lack of relevant takeover case law in the period when hostile takeovers became a key battleground for shareholders and directors offers important insight into the explanation of the lack of recent tradition of management independence in the United Kingdom.

158. See id. at 266; see also Shuangge Wen, The Magnitude of Shareholder Value as the Overriding Objective in the UK: the Post-crisis Perspective, 26 J. INT'L BANKING L. \& REG. 325 (2011).

159. See id.

160. Dawson Int'1 PLC v Coats Patons PLC, [1989] BCLC 233, 314.

161. Some observers believe that the discretion may be unlimited in the context of asset sales. See Gerner-Beuerle et al., supra note 152, at 16.

162. See John E. Parkinson, Corporate Power and Responsibility: IsSues in the THEORY OF COMPANY LAW, at ch. 3 (1993); see also KAY, INTERIM REPORT, supra note 117, at 1213. 


\section{The Shareholder Coup}

As noted above, a hostile takeover of the Savoy Hotel group was attempted in 1954. ${ }^{163}$ The successful defensive behavior of the Savoy board in the takeover led to the appointment of a government inspector who, although he considered that the Savoy management had exceeded their authority, ultimately set out a legal proposition that allowed a balance between board discretion over shareholder compulsion. ${ }^{164}$ Emboldened by its success and concerned by the possibility of future takeover attempts, the board of the Savoy Hotel group, led by Hugh Wontner, subsequently put in place a system of weighted voting rights designed to make future takeovers impossible. ${ }^{165}$ The general disapproval of the Savoy board's behavior proved pivotal in the development of takeovers in the United Kingdom. As The Economist wrote at the time, "[o]n grounds of principle, it is difficult to find condemnation too severe for what the Savoy Hotel board have done." 166

In 1958, British Aluminum (BA) received a takeover offer from Alcoa and a joint bid by Tube Investments and Reynolds Metals. ${ }^{167}$ Without involving shareholders, BA's board, led by Lord Portal, rejected the higher Tube-Reynolds bid in favor of Alcoa's offer. ${ }^{168}$ This occurred at a time when hostile takeovers were still unusual and U.K. institutional investors (primarily pension and insurance funds) were a growing force. ${ }^{169}$ Portal and the BA board attempted to defend the company in an aggressive manner similar to the Savoy board's defense. ${ }^{170}$ The proposition in the report on the Savoy takeover arguably left significant discretion to the board. ${ }^{171}$ The behavior of the BA board-its exclusion of the current shareholders and effort to fight off the hostile bid-tested this

163. See Holland, supra note 143.

164. See L.C.B. Gower, Corporate Control: The Battle for the Berkeley, 68 HARV. L. REV. 1176, 1192-93 (1955). In the balanced interpretation of the duty to the company, current and future shareholders came not from the inspector but from the lawyers for the Savoy board.

165. See THE ECONOMIST, Dec. 12, 1953, at 45.

166. Id.; see Gower, supra note 164, at 1176.

167. John Armour \& David A. Skeel, Jr., Who Writes the Rules for Hostile Takeovers, and Why? - The Peculiar Divergence of US and UK Takeover Regulation, 95 GEO. L.J. 1727 (2007).

168. See Aluminium Share Deal: Lord Portals Statement, GlaSgOw Herald, (Dec. 6, 1958), at 1 ; available at http://news.google.com/newspapers?id=ymhAAAAAIBAJ\&sjid=XpUMAAA AIBAJ\&pg=3105\%2C4485899; British Aluminium Rejoinder: "An Empire for a Kingdom," GLASGOW HERALD (Dec. 6, 1958), at 2, available at http://news.google.com/newspapers?id=y mhAAAAAIBAJ\&sjid=XpUMAAAAIBAJ\&pg=1814\%2C4491452.

169. BRIAN R. CheFFins, CORPORATE OWNERShIP AND CONTROL: British Business Transformed 344-45 (2008); see also Alan J. Dignam \& Michael Galanis, The GLOBALIZATION OF CORPORATE GOVERNANCE 303-92 (2009).

170. See Armour \& Skeel, supra note 167, at 1758.

171. See HollaND, supra note 143. 
proposition. ${ }^{172}$ Nevertheless, the hostile takeover eventually succeeded due to a combination of coordinated action by institutional investors and enormous public disapproval of the perceived self-serving activity of the board. ${ }^{173}$

The ensuing reaction of institutional investors was the most significant result of the takeover attempt on Savoy Hotel and the successful takeover of BA. Under pressure from institutional investors, the Bank of England secretly set up a working group to examine hostile takeovers. ${ }^{174}$ While there was no director representative on the working group, institutional investors were strongly represented. ${ }^{175}$ The group produced a set of guidelines, known as the "Notes of Amalgamations of British Business," based on the principle that shareholders, not the board, make the key decision on a takeover. ${ }^{176}$ Although these notes were admired, they were not adopted universally. After another Bank of England consultation in 1968, the Panel on Takeovers and Mergers (the Panel) was formed as a self-regulating body to police takeovers in the United Kingdom through the administration of a code on takeovers and mergers. ${ }^{177}$ Directors as well as institutional investors were included in the consultation this time, but the outcome was the same: the code was based on central guiding principles propounded by the institutional investors of informed shareholder decisionmaking and board neutrality. ${ }^{178}$

The formation of the Panel marked a crucial point in the development of the law regarding directors' discretion in the United Kingdom. Up until this point, directors had a significant discretionary power as judicial development of corporate law sought to balance management independence with shareholder accountability as discussed above. The formation of the Panel to enforce strongly-shareholder-oriented rules in a key arena marked the point when corporate law ceased to be the major influence on directors' discretionary powers, and current shareholders became the focus of the exercise of directors' powers. The change effectively removed the courts from their role of interpreting the balance of

172. For a discussion of the extent of board discretion at the time, see DAVIES \& GOWER, supra note 126, at 55; see also CHEFFINS, supra note 169, at 328-33; RONALD W. MOON, BUSINESS MERgers and TAKe-Over Bids: A Study of THE Post-War PATtern of AMAlgamations AND RECONSTRUCTIONS OF COMPANIES 128-32 (5th ed. 1976).

173. See Armour \& Skeel, supra note 167.

174. Id. at 1759 .

175. Id. at 1758; see also Paul L. Davies, The Regulation of Defensive Tactics in the United Kingdom and the United States, in EuropeAn TAKEOVERS: LAW AND PraCTICE 200 (Klaus J. Hopt \& Eddy Wymeersch eds., 1992).

176. Davies, supra note 175, at 200; see also ALEXANDER JOHNSTON, THE CiTY TAKE-OvER CODE (1980)

177. Davies, supra note 175 , at 200.

178. Armour \& Skeel, supra note 167, at 1759. 
power within the British corporation because, from this point on, the Panel enforced a board-neutrality rule, and takeover cases rarely fell to the courts to determine. A subtle coup had occurred whereby a private body came to regulate one of the most important aspects of U.K. corporate law, not in the public interest, but in the interest of a self-serving group-shareholders. As a result, there was an enormous legitimacy deficit in the operation of a private body working outside the public interest staffed by representatives of the financial, legal, and accounting services sectors enforcing a code that favors one particular interest group. ${ }^{179}$

Over the course of the 1970s and 1980s, takeovers became more common, and hostile takeovers in particular exploded in number, accounting for a quarter of all mergers and acquisitions between 1970 and 1990. ${ }^{180}$ With these takeovers came an expansion of the Panel's and the code's importance, along with increased tension about their legitimacy. A challenge to a decision of the Panel put this legitimacy gap under the spotlight in $1987 .{ }^{181}$

In $R$ v. Panel on Takeovers \& Mergers ex parte Datafin PLC, the court of appeal had to decide if the Panel's decisions were judicially reviewable because even though the Panel was a private body, it was effectively carrying out a quasi-public function. ${ }^{182}$ The court found that the Panel's quasi-public function did make the case judicially reviewable. But the court of appeal declined to review the Panel's decisions until the takeover was complete. ${ }^{183}$ In practicality, this approach made it useless to seek judicial review of a Panel decision. The decision, while recognizing the quasi-public function, maintained and indeed enhanced the Panel's jurisdiction over takeovers, providing a cloak of public sector legitimacy with private sector protection. ${ }^{184}$ As a result, board influence on the outcomes of takeovers further dwindled and with it their general discretionary power in arguably the most important decisionmaking arena of cor-

179. For additional information on the Panel, including its mission, organization, and membership, see About the Panel, THE TAKEOVER PANEL, http://www.thetakeoverpanel.org.uk/structure/ about-the-panel (last visited Nov. 19, 2012).

180. See Geoffrey Jones, Great Britain: Big Business, Management and Competitiveness in Twentieth-Century Britain, in Big Business AND THE WeAlth OF NATIONS 136 (Alfred D. Chandler, Franco Amatori \& Takashi Hikino eds., 1997); see also Julian Franks \& Colin Mayer, Hostile Takeovers and the Correction of Managerial Failure, 40 J. FIN. ECON. 163 (1996); Julian R. Franks \& Robert S. Harris, Shareholder Wealth Effects of Corporate Takeovers: The UK Experience 19551985, 23 J. FIN. ECON. 225 (1989).

181. See [1987] QB 815.

182. See id.

183. See id.

184. See id. 
porate life. ${ }^{185}$ Shareholder decisionmaking and management neutrality became an accepted norm in the area of takeovers.

To be fair to the Panel, it has always been deeply uncomfortable with the idea of being a quasi-public body, and prior to the domestic implementation of the E.U. Takeovers Directive, it vigorously resisted being made a statutory body in the Companies Act 2006. ${ }^{186}$ That resistance was ultimately futile, and it now operates in very uncomfortable territory as a formal statutory body acting without a public interest mission. ${ }^{187}$ As the Panel stated in evidence to the Kay Review in 2012,

The financial and commercial merits of takeovers are not the responsibility of the Panel. These are matters for the companies concerned and their shareholders. In addition, it is not the purpose of the Code either to facilitate or to impede takeovers. Nor is the Panel responsible for competition policy or wider questions of public interest, which are the responsibility of government and other bodies. $^{188}$

In short, although the Panel would not see it this way, the Panel has subverted a key area of corporate law in the United Kingdom and created a regulatory regime where shareholders make the key decisions in a takeover without interference from the board. The managementneutrality rules of the Panel weigh heavily on the way takeovers proceed and the way executives receive legal advice, even if management has genuine concerns about the takeover. ${ }^{189}$ In 2012, the Kay Review noted,

Sir Roger Carr, describing his experience as chairman of Cadbury during the takeover bid from Kraft, told us that the board did not believe it was possible to reject a high bid that reflected full value for

185. See generally T.E. Cooke, R.G. Luther \& B.R. Pearson, The Information Content of Defence Documents in UK Hostile Takeover Bids, 25 J. Bus. FIN. \& ACCT. 115 (1998) (examining the contents of management defense documents and concluding that the management in target companies was unable to introduce new information in their defense documents that materially affected the outcome of a bid); see also TIM JENKINSON \& COLIN P. MAYER, Hostile TAKEOVERS: DEFENCE, ATTACK AND CORPORATE GOVERNANCE 24 (1994).

186. See Blanaid Clarke, European Union Articles 9 and 11 of the Takeover Directive (2004/25) and the Market for Corporate Control, 50 J. BuS. L. 355, 374 (2006); see also DEP'T OF TRADE \& INDUS., COMPANY LAW IMPLEMENTATION OF THE EUROPEAN DiRECTIVE ON TAKEOVER Bids: A CONSUltative DOCUMENT (2005), available at http://www.dti.gov.uk/files/file10384.pdf; DEP'T OF TRAdE \& INDUS., COMPANY LAW REFORM, at ch. 3.6 (2005), available at http://webarchive.nationalarchives.gov.uk/+/http://www.dti.gov.uk/cld/WhitePaper.pdf.

187. This became a source of some difficulty during the Kraft takeover of Cadbury in 2010. In Depth: Cadbury - Kraft, FIN. TIMES, http://www.ft.com/indepth/cadbury-kraft (last visited Nov. 18, 2012).

188. KAY, INTERIM REPORT, supra note 117, at 13.

189. See Criterion Properties PLC v. Stratford UK Properties LLC, [2004] 1 W.L.R. 1846 (containing the advice given by Ashurst Morris Crisp to Oaktree on the effect of the Panel's nonfrustration rule). 
the business even if they considered that the long term success of the company may best be achieved if it remained independent. ${ }^{190}$

The corporation has been dematerialized by this focus solely on current shareholders. In the United Kingdom, corporate law provides that the director's duty is owed to the corporation and that in turn a balance should be maintained between the interests of short- and longer-term shareholders as well as, since the Companies Act 2006, the consideration of a range of stakeholder issues. ${ }^{191}$ However, in the operation of the code and the Panel, that duty has become an obligation solely to current shareholders.

This development has enormous impact, as the key decision on the company's future does not fall to the board as it does in other jurisdictions. In other jurisdictions, judicial interpretation of corporate law maintains the balance of power between the shareholders and the board. ${ }^{192}$ As a result, the incremental development of the balance of power that one observes in the United States on the business judgment rule and board powers in a takeover ${ }^{193}$ has been subverted in the United Kingdom by the Panel and the code, resulting in a strict current-shareholder-centric corporate governance system. In effect, there is no key case on the extent of board discretion versus shareholder accountability in U.K. corporate law because the area that produces the central tension between shareholder and board power has been captured by a shareholder representative body acting to the exclusion of the board, the stakeholders, and the company. By 2012, evidence provided to the Kay Review indicated that U.K. boards had internalized a short-term current-shareholder-centric view of their corporate law duties. ${ }^{194}$ Boards have come to believe not only that their legal duty was owed to current shareholders but also that this was normatively appropriate. ${ }^{195}$ But this evolution did not just occur because of the Panel, it arose as a part of a larger cultural and theoretical change.

\section{The Larger Context: Cultural and Theoretical Change}

The changing theoretical and cultural understanding of the role of directors also impacted directors' discretion. In the 1950s, there was a

190. See KAY, INTERIM REPORT, supra note 117 , at 13.

191. The introduction of stakeholder obligations is discussed in Part III.D below.

192. Lyman P.Q. Johnson, Corporate Officers and the Business Judgment Rule, 60 Bus. LAW. 439 (2005) (discussing the business judgment case law). The development of management powers in a takeover is illustrated in Air Prods. \& Chems., Inc. v. Airgas, Inc., 16 A.3d 48 (Del. 2011); Unitrin, Inc. v. Am. Gen. Corp., 651 A.2d 1361 (Del. 1995); Unocal v. Mesa Petroleum Co., 493 A.2d 946 (Del. 1985).

193. See id.

194. See KAY, INTERIM REPORT, supra note 117 , at 12. 195. Id. at $12-13$. 
broad consensus across U.K. industry, academia, and government that management owed duties not just to shareholders but also to employees and the community. ${ }^{196}$ This broad consensus did not last, and by the 1960 s, self-interested board behavior was attracting disquiet from shareholders, government, academia, and the judiciary. ${ }^{197}$ Simultaneously, the post-war period saw significant change in the nature of shareholding as families divested their shares and institutional investors (pension funds and insurance companies), incentivized by a favorable tax regime, replaced them. ${ }^{198}$ Additionally, as discussed above, the developing market for corporate control revealed board abuse of power and incentivized shareholders to exert control over British boards. ${ }^{199}$

From the 1960s onward, a very broad range of scholars turned to consider corporations, managers, and the state's regulatory role. The outcome of that scholarship was largely negative for directors. In the 1960s, the work of managerial economists such as Williamson and Marris began to show that concerns from commentators such as Berle about board abuse of power had substance. ${ }^{200}$ By the 1970 s, economic, political, and legal theories moved strongly against board discretion and the state as a positive force. Shareholders' empowerment, built on a contractual foundation, moved center stage. ${ }^{201}$

In 1974, Robert Nozick published his classic work Anarchy, State, and Utopia, arguing for a reordering of the world based on freedom to contract and a minimalist state. ${ }^{202}$ Nozick's work provided the moral intellectual force for a political and economic free market ideology based on freedom to contract and the protection of private property that would come to dominate the late twentieth and early twenty-first centuries. ${ }^{203}$ Similar developments flourished among academics studying theories of the firm and corporate governance. In 1972, Alchian and Demsetz ${ }^{204}$ at-

196. See Gower, supra note 164, at 1190; see also CHEFFINS, supra note 169, at 340-41.

197. See Gower supra note 164, at 1176. The decision in Parke v. Daily News Ltd., [1962] Ch. 927, raised serious concerns about directors' ability to directly benefit employees that was only resolved through legislation in the 1980 s.

198. ChEFFINS supra note 169; see also DignAM \& GALANIS, supra note 169.

199. See, e.g., Davies, supra note 175 (discussing the reasons for the formation of the Takeovers Panel).

200. See generally Oliver E. Williamson, THE ECONOMICS OF DisCRETIONARY BEHAVIOR: Managerial ObJectives in a THeORy of the Firm 34-37 (1964); Robin Marris, The ECONOMIC THEORY OF MANAGERIAL CAPITALISM (1964)

201. See Armen A. Alchian \& Harold Demsetz, Production, Information Costs, and Economic Organization, 62 AM. ECON. REV. 777 (1972); see also Michael C. Jensen \& William H. Meckling, Theory of the Firm: Managerial Behaviour, Agency Costs, and Ownership Structure, 3 J. Fin. ECON. 305, 307 (1976).

202. See generally ROBERT NOZICK, ANARCHY, STATE, AND UtOPIA (1974).

203. See id.

204. See Alchian \& Demsetz, supra note 201. 
tempted to provide a new theory of the firm by disputing the primary role of the board in the firm and placing the shareholders in the key accountability role.

In 1976, Jensen and Meckling ${ }^{205}$ added to the new-theory analysis by emphasizing the contractual foundation of the firm and arguing that the relationship between the shareholders and board was that of agent and principal in which agency costs were significant. Agency-costreducing mechanisms, like the efficient operation of the market for corporate control, high levels of debt, competitive markets, and disclosure, reduce directors' ability to satisfy their self-interest. ${ }^{206}$ If the firm generates a discretionary cash surplus, this should therefore be returned to the shareholders to replicate the effect of debt on management. The new theoretical approach provided additional tools to attack board power and emphasize the role of shareholders as principals. The shareholder moved to center stage, and the corporation began to dematerialize.

Of equal significance were the normative implications of these new theories rooted in neoclassical economics because they diminished the role of the state in balancing the needs of stakeholder constituencies within and without companies. If one accepts that the corporation no longer exists and that a private contractual concern is at issue, then state interference in its activities becomes more difficult to justify, and the methods by which it is acceptable to interfere become more restrictive. Mandatory rules, which override any market-based private agreements between contracting parties, and any rules that interfere with the efficient operation of the marketplace, are therefore unacceptable in a new-theory analysis. ${ }^{207}$ For example, mandatory company law provisions that impede takeovers would offend both aspects of the theory. Thus, the state's role is reduced to the following: (1) facilitating private contracting arrangements through enforcement; (2) providing default rules that apply in the absence of any agreement to the contrary (for example, the model articles); and (3) creating enabling rules that provide a framework for private parties to carry out certain functions, such as shareholder-oriented disclosure rules or rules that wind up the company in an insolvency. The new theory's strength was its ability to provide clear, certain answers to many uncertain aspects of corporate behavior. In particular, it could easily solve any board accountability issues because of its laser-like focus on shareholder accountability. Professor Bratton described its impact in the early 1980s:

205. See Jensen \& Meckling, supra note 201.

206. DignAM \& GALANIS, supra note 169 , at 31-34.

207. See id. at 21. 
The new theory's proponents made strong claims on its behalf. The economists who originated it proclaimed a major discovery: Professor Michael Jensen, for example, predicted that this infant "science of organizations" will produce a "revolution ... in our knowledge about organizations" during "the next decade or two ...." In the law schools, its enthusiasts moved aggressively for equal academic status. $^{208}$

Both Nozick's work and the new theory had answers and impact. In the United Kingdom, the shrinking of the state through the privatization of state assets and concomitant incentives for holding shares created a "public" shareholding class and accelerated the practical rise of institutional investors capable of reducing agency costs through the market for corporate control and encouraging extensive disclosure. ${ }^{209}$ Hansmann and Kraakman, writing in the early twenty-first century, describe the effects:

[A] final source of ideological convergence on the standard [shareholder] model is a fundamental realignment of interest group structures in developed economies. At the center of this realignment is the emergence of a public shareholder class as a broad and powerful interest group in both corporate and political affairs across jurisdictions.

There are two elements to this realignment. The first is the rapid expansion of the ownership of equity securities within broad segments of society, creating a coherent interest group that presents an increasingly strong countervailing force to the organized interests of managers, employees, and the state. The second is the shift in power, within this expanding shareholder class, in favor of the interests of minority and noncontrolling shareholders over those of inside or controlling shareholders. ${ }^{210}$

Having an exclusive shareholder as "owner" of the corporation became an accepted norm culminating in the voracious hostile takeovers and corporate excess of the 1980s. As Goyder noted in the late 1980s, "[t]he usurious outlook, which treats a company as shareholders' property instead of as a living organism, simply cannot see the daylight. The 'City' view, and its preoccupation with short-term gains, is alien to the

208. William W. Bratton, Jr., The New Economic Theory of the Firm: Critical Perspectives From History, 41 STAN. L. REV. 1472 (1989).

209. See generally Michael E. Beesley \& Stephen C. Littlechild, The Regulation of Privatized Monopolies in the United Kingdom, in Privatization, REgUlation AND DeREgulation 55-78 (M.E. Beesley ed., 1992); see also DignAM \& GALANIS, supra note 169, at 237-61.

210. Henry Hansmann \& Reinier Kraakman, The End of History for Corporate Law 14-15 (Yale Law Sch., Working Paper No. 235, 2000), available at http://papers.ssrn.com/sol3/pap ers.cfm?abstract_id $=204528$. 
whole concept of industrial and commercial partnership over a long time span." "211 This changing theoretical and cultural landscape, combined with the shareholder capture of takeovers, swamped the careful judicial crafting of a corporation with an independent board. The judicial construct ceased to match the reality of the reflective cultural and theoretical corporation "owned" by shareholders. Instead, the board was viewed solely in terms of negative agency costs. The change created a new primary goal for shareholders, regulators, and markets: reduce board discretion.

If one can identify a general tipping point in the United Kingdom it came with the failure of consensus between the parties of industry in The Report of the Committee of Inquiry on Industrial Democracy. ${ }^{212}$ The committee was set up in 1975 to explore the inclusion of employees in the decisionmaking of British companies. In 1977, when the committee was due to report, the committee could not agree on a single unified report and instead produced two reports. The majority report, known as the Bullock report, achieved the agreement of the chair, the unions, the academics, and a city solicitor on the committee. It advocated for employee participation on a unitary board and portrayed the interest of the company in pluralist terms. The minority report, produced by the industrialist members of the committee, disagreed and advocated for a split board and a view of shareholders as owners and the primary constituency to which directors owed their duties. ${ }^{213}$ Despite this Berle-Dodd moment, many viewed Britain as about to enter a period of significant pluralist organizational change as a result of the majority Bullock report. As Davies and Wedderburn concluded in 1977, "[t] he advance to industrial democracy that will come in Britain now seems likely to progress both through extended bargaining and by means of new powers for workers established in company law, of the kind adumbrated in Bullock." 214 The report did signal change, but it was the minority-report view on the importance of shareholders that accurately signaled the way ahead.

In an environment where shareholder "ownership" of the corporation is a strong cultural and theoretical norm and takeovers are decided by shareholders, a nuanced legal discretion to take a long-term view can easily become a shareholder-focused one as it falls to directors to interpret. Directors came to believe in the necessity for their own restraint and

211. GeOrge Goyder, THE JUST ENTERPRISE 95-96 (1987).

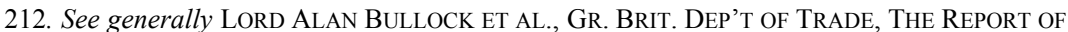
THE COMMITTEE OF INQUIRY ON INDUSTRIAL DEMOCRACY, Cmnd. 6706, 1977 (U.K.).

213. See generally id.

214. Paul Davies \& Lord Kenneth William Wedderburn, The Land of Industrial Democracy, 6 INDUS. L.J. 197, 211 (1977). 
developed a form of corporate Stockholm syndrome in choosing to believe that current-shareholder value and future-shareholder interests were one and the same. ${ }^{215}$ This is particularly so given the rise of the MBA in the United Kingdom as a senior management qualification and its concomitant production of shareholder-value-maximizing executives. ${ }^{216}$

The pursuit of current shareholders' interests to the exclusion of other interests becomes the simpler and easier option for directors, especially if sweetened by huge remuneration incentives. The maximization of current-shareholder interests is driven by the nuanced complexity of the legal duty, the dominance of the shareholders' interest - both current and future - in that duty, the takeover code, and general cultural norms of shareholder "ownership" of the corporation since the $1980 \mathrm{~s} .{ }^{217}$ Lord Wedderburn of Charlton noted in the early 1990s that

[t]he shareholder's property in his share and the "interests of the company" as the shareholders' interests alone, became pillars of the modern law with no plurality of other interests acknowledged (such as those of the employees) as they have, in whole or in part, been accepted by neighbouring company laws as a natural and necessary part of their enterprise law. ${ }^{218}$

But this phenomenon did not go unnoticed. By the 1990s, the focus of directors solely on shareholders had become a matter of concern as a public debate arose about corporations owing wider duties to "stakeholders." 219 Academics and the media expressed general public concerns that shareholder-centric market forces had a detrimental effect on employees and communities. ${ }^{220}$ Employment reform in the 1980s had made it easier and less costly for companies to dismiss employees. This was followed by post-privatization employee rationalization, and a booming market in takeovers and mergers had resulted in employees' further rationalization. ${ }^{221}$

215. See KAY, INTERIM REPORT, supra note 117, at 12-13.

216. Ctr. for Bus. Educ., Aspen Inst., Where Will They Lead? MBA Student ATTITUDES ABOUT BuSINESS AND SOCIETY (2008), available at http://www.aspencbe.org/doc uments/ExecutiveSummaryMBAStudentAttitudesReport2008.pdf; see also CADBURY ET AL., supra note 103 , at para. 1.18 (explicitly making this connection).

217. For a discussion of the rise of the shareholding democracy, see Paddy Ireland, Shareholder Primacy and the Distribution of Wealth, 68 MoD. L. Rev. 49 (2005).

218. Lord Kenneth William Wedderburn, Companies and Employees: Common Law or Social Dimension?, 109 L.Q.R. 220, 261 (1993); see also Lord Kenneth William Wedderburn, The Social Responsibilities of Companies, 12 MELBOURNE U. L. REV. 1 (1982).

219. See generally Will HutTON, THE STATE WE'Re IN (1995); PARKInSON, supra note 162.

220. See PARKINSON, supra note 162, at 201.

221. See John Rentoul, Privatisation: The Case Against, in Privatisation: FAIR SHARES FOR All OR SElling THE FAMILY Silver? 2 (Julia Neuberger ed., 1987); see also Alan Arthurs, Indus- 
Boards in the United Kingdom also appeared to be particularly focused on the short-term goal of pushing higher proportions of wealth generated by the company to the shareholders as dividends rather than reinvesting it in the company. ${ }^{222}$ This reduced the financial cushion that management might have had if there was a downturn in the economy. ${ }^{223}$ As a result, the combined effect of market-based shareholderperformance measures and employment reform made it an easy choice for boards to cut costs by dismissing employees. At the same time, directors' salaries increased enormously. ${ }^{224}$

In the early 1990s, the sudden collapse of a number of high-profile companies $^{225}$ proved a turning point. Corporate governance reform became a political issue that engaged a self-regulatory response of industry to some of these issues through the Cadbury, Greenbury, and Hample corporate governance reports. These self-regulating committees, again as with the takeover code, were heavily influenced by institutional investor concerns. ${ }^{226}$ The committees put in place a corporate governance code ${ }^{227}$ focused on further reducing managerial power through the use of NEDs, and on constraining and legitimizing executive remuneration through disclosure. ${ }^{228}$ On the first goal, the committees were successful. But on the second goal, and on the growing issue of corporate social responsibility, the committees failed to provide solutions. ${ }^{229}$

trial Relations in the Civil Service: Beyond GCHQ, 16 InDUS. REL. J. 26 (1985); K.D. Ewing, Industrial Action: Another Step in the "Right" Direction, 11 InDUS. L.J. 209 (1982).

222. See Helen Short, Hao Zhang \& Kevin Keasey, The Link Between Dividend Policy and Institutional Ownership, 8 J. CORP. FIN. 105 (2002).

223. In effect, companies seemed to be adopting an agency-cost-reducing model where discretionary surplus cash flow is distributed to the shareholders. See generally Andrei Shleifer \& Lawrence H. Summers, Breach of Trust in Hostile Takeovers, in CORPORATE TAKEOVERS: CAUSES AND CONSEQUENCES (Alan J. Auerbach ed., 1998).

224. See PARKINSON, supra note 162, at 201.

225. The collapses of the Bank of Credit and Commerce International and the Polly Peck and Maxwell companies through massive audit corruption were very similar to the later collapses in the United States of Enron and WorldCom. See Dan Roberts, Why Enron Did Not and Should Not Happen Here, Fin. Times (May 27, 2006),

http://www.ft.com/cms/s/0/5e8e35ec-ed1d-11da-a307-0000779e2340.html

226. The Institutional Shareholders Committee produced a similar corporate governance agenda immediately before the Cadbury report. See InST'L SHAREHOLDERS COMM., The RESPONSIBILITIES OF INSTITUTIONAL INVESTORS IN THE UK (1991), available at http://www.ivis.co.uk/ResponsibilitiesOfInstitutionalShareholdersInTheUK.aspx.

227. This is now combined into the U.K. Corporate Governance Code. See FIN. RePORTING COUNCIL, supra note 106.

228. CADBURY ET AL., supra note 103; GREENBURY ET AL., supra note 103; HAMPEL ET AL., supra note 103.

229. The growing concern about corporate social responsibility was epitomized by the popularity of the book by Will Hutton, The State We're in: Why Britain Is in Crisis and How to Overcome It (1996). 
The election of a Labour government in 1997 brought with it a change in regulatory ethos away from self-regulation. Within a few years, the Bank of England was removed as the primary financial regulator because it was viewed as being too closely tied to those it regulated. A raft of self-regulating organizations in the financial sector, including the London Stock Exchange, were placed under the control of the new FSA, modelled on the U.S. Securities and Exchange Commission. ${ }^{230}$

The new government also targeted the corporate governance committees. Tony Blair had identified himself with the concept of stakeholders throughout the 1997 election campaign. And Margaret Beckett, who became the Minister of the Department of Trade and Industry (DTI, now the BIS) in 1997, was particularly committed to socially responsible corporate governance reform. ${ }^{231}$ She focused on the Hampel committee before its final report in 1998 and asked it to address wider corporate governance concerns. ${ }^{232}$ Indeed, when she concluded that the report had failed to provide sufficient reform, the DTI included corporate governance reform firmly in the remit of its major company law review. ${ }^{233}$

Thus, the incoming government set up a flagship general review of company law but with a specific committee chaired by Professor John Parkinson to explore the scope of company law and in particular the issues of directors' duties and stakeholder participation. ${ }^{234}$ Professor John Parkinson was the author of the most important and influential U.K. legal work in the early 1990s, Corporate Power and Responsibility: Issues in the Theory of Company Law. ${ }^{235}$ In the first chapter, Parkinson established his view that shareholders have no moral entitlement to primacy in company law. ${ }^{236}$ He then built a strong case for corporate social responsibility. ${ }^{237}$ The importance of the work was in the case Parkinson built for

230. See Iain MacNeil, The Future for Financial Services Regulation: The Financial Services and Markets Bill, 62 MOD. L. REV. 725 (1999).

231. Co. Law \& Investigations Directorate, Dep'T of Trade \& Indus., Modern COMPANY LAW FOR A COMPETITIVE ECONOMY 21 (1998), available at http://www.bis.gov.uk/files/ file23283.pdf; Antony Barnett, Interview: Margaret Beckett, GuARDIAN (Nov. 9, 1997), http://www.guardian.co.uk/politics/1997/nov/09/labour.uk; Gavyn Davies, Tony Blair Puts Meat on the Stakeholder Bones, INDEPENDENT (Jan. 15, 1996), http://www.indep endent.co.uk/news/ business/tony-blair-puts-meat-on-the-stakeholder-bones-1324167.html.

232. See Jim Kelly, David Wighton \& Andrew Bolger, The Hampel Report: DTI Gives Guarded Welcome Ahead of Review, Fin. TIMES, Jan. 29, 1998, at 11.

233. Co. LAW \& INVESTIGATIONS DiRECTORATE, supra note 231.

234. For a discussion of the reform process, see Ben Pettet, Towards a Competitive Company Law, 19 Company LaW. 134 (1998). See also Co. LaW Review Steering Grp., Dep't of Trade \& INDUS., MODERN COMPANY LAW FOR A COMPETITIVE ECONOMY: THE STRATEGIC FraMEWORK 33-55, 161 (1999), available at http://www.bis.gov.uk/files/file23279.pdf.

235. PARKINSON, supra note 162.

236. Id. at ch. 1.

237. Id. 
corporate social responsibility and in his active engagement with the contractarian model, which he seems to defeat, to the palpable relief of many company lawyers all over the United Kingdom. ${ }^{238}$ His presence at the head of the committee signaled that corporate social responsibility was being taken seriously. ${ }^{239}$

Still, corporate governance reform was a sensitive area for the new socialist government as it had an uncertain relationship with the business community. ${ }^{240}$ For a while, things went well, and Parkinson's corporate governance committee explored a wide range of pluralist ideas. ${ }^{241}$ But in time this freedom was curtailed, and the corporate governance committee focused only on "enlightened shareholder value," a vague reformulation of the directors' duty to act in the interests of the company and to provide encouragement to enlightened managers who might have stakeholder concerns. ${ }^{242}$ That was pretty much where it stood until the final report. ${ }^{243}$ The Companies Act 2006 eventually emerged, and section 172, the "enlightened shareholder value" provision, reads as follows:

\section{Duty to promote the success of the company}

(1) A director of a company must act in the way he considers, in good faith, would be most likely to promote the success of the company for the benefit of its members as a whole, and in doing so have regard (amongst other matters) to -

(a) the likely consequences of any decision in the long term,

(b) the interests of the company's employees,

(c) the need to foster the company's business relationships with suppliers, customers and others,

(d) the impact of the company's operations on the community and the environment,

238. Id.

239. Keith Stanton \& Lady Justice Mary Arden, Obituary: John Parkinson, GuARDIAN (Apr. 8, 2004), http://www.guardian.co.uk/news/2004/apr/09/guardianobituaries.

240. One of its first high-profile acts was to introduce a retrospective tax on the privatized former-state companies. This did not instill confidence in the business community. See M. Irving, New Deal Comes Up Trumps, GuARdian, Dec. 19, 1998, at 12.

241. Co. LAW REVIEW STEERING GRP., supra note 234, at 33-55.

242. Co. Law Review SteEring GrP., Modern COMPany LaW for a COMPetitive ECONOMY: COMPLETING THE STRUCTURE, at ch. 3 (2000), available at http://webarchive.national archives.gov.uk/20100409214757/berr.gov.uk/whatwedo/businesslaw/co-act-2006/clrreview/page25080.html.

243. Co. Law Review Steering Grp., Modern Company LaW for a Competitive ECONOMY: FINAL REPORT, at ch. 3 (2001), available at http://www.classfn.com/Compa nies\%20Formation/modern_company_law/modern_company_law.html 
(e) the desirability of the company maintaining a reputation for high standards of business conduct, and

(f) the need to act fairly as between members of the company. ${ }^{244}$

Although unenforceable by any constituency other than shareholders, the reformulated director's duty remains focused on shareholders (members) but does specify the need to have regard for certain issues (namely, the long term) and certain constituencies (suppliers, customers, employees, community, and the environment). In that sense, it is not significantly different than the old, nuanced, and judicially formulated duty allowing directors a Savoy-esque discretion. In a similar way, the duty remains up to the director to interpret within the dominant cultural, theoretical, and practical context of shareholders as owners. As such, it could technically provide a shield to enlightened boards should they wish to justify a course of action in terms of shareholders and other constituencies. To do that though, one needs "enlightened" boards, but as noted above, directors have come, culturally and practically, to understand their legal obligations when exercising their powers as being owed to current shareholders. ${ }^{245}$ In addition, directors often see that duty as going further and compelling them to maximize returns to shareholders in the short term. ${ }^{246}$ The Kay Review addressed this issue:

The ACCA [Association of Chartered Certified Accountants] drew attention to a study undertaken on its behalf by Professor Collison. He reported that the corporate executives in his study seemed to interpret the law as imposing a requirement to maximise the share price in the short term. It seems unlikely that Professor Collison's respondents did not know what the law was: these responses may therefore illustrate their state of mind rather than their understanding of the law. ${ }^{247}$

By the second decade of the twenty-first century, the corporate governance system in the United Kingdom, through the operation of the takeover panel, agency-cost-reducing initiatives, a missing judicial balance of power, as well as shareholder-centric cultural and theoretical norms, had created an ecosystem in which little concept of independent board power remained.

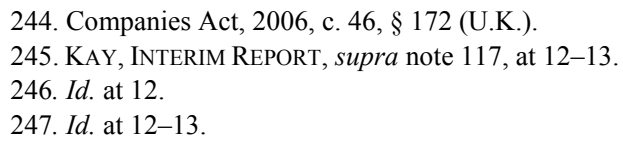




\section{OWNERLESS CORPORATIONS OR SHAREHOLDERS ON STEROIDS?}

The activities of bank shareholders and boards in the lead-up to the financial crisis signaled not just that there would be an impending collapse of the sector but also that a significant, broader corporate governance revolution was taking place. Lord Myners, in response to questions by the Treasury select committee about shareholder responsibility for the banking crisis, explained that an important change was occurring in the makeup of shareholdings of all major listed companies, not just banks, where shareholding had become disparate and institutional investors were no longer significant. ${ }^{248} \mathrm{He}$ concluded that "we have to some extent ownerless corporations." ${ }^{249}$ While Lord Myners is correct to identify a significant change, his characterization of corporations in terms of ownership by shareholders continued to mistakenly portray positive corporate governance change in terms of shareholder "ownership." As discussed in Part II of this Article, shareholders should have shouldered significant blame for the collapse of the U.K. banks and the ongoing social costs. ${ }^{250}$ Instead, shareholder passivity and the idea of positive "ownership" in the form of stewardship have been accepted and applied to all listed U.K. corporations. ${ }^{251}$ Rather than learning the lesson that we may have a "bad" shareholder problem, we have insisted - in the Walker Review and the subsequent Kay Review, as well as in BIS proposals on mandatory say on pay - that the solution is to enhance shareholder power and encourage strategic engagement. ${ }^{252}$ This is a recipe for trouble given that shareholders' short-term strategic focus played such a disastrous role in the banking crisis and is beginning to manifest itself outside banking corporations.

Lord Myners is, however, right in identifying that an important change is occurring in our shareholding base. Our traditional institutional shareholders in the form of pension, insurance, and general investment funds, who built the U.K.'s shareholder-centric corporate governance system to suit their needs, have begun to withdraw. ${ }^{253}$ The drivers of this exodus have been legislative and accounting changes as well as pensionmembership demographics changing to favor current returns. ${ }^{254}$ They

248. TREASURY COMM., supra note 34, at 64.

249. Id.

250. See supra Part II ("THE SHADOW"); see also Daniel Ferreira et al., Shareholder empowerment and Bank Bailouts (European Corp. Governance Inst., Finance Working Paper No. 345, 2013), available at $\mathrm{http}: / /$ ssrn.com/abstract=217039 (finding that banks with powerful shareholders performed poorly during the crisis)

251. FIN. REPORTING COUNCIL, supra note 102.

252. See supra Part II ("THE SHADOW").

253. Cheffins, supra note 2, at 24-36; KAY, FINAL REPORT, supra note 3, at 30-31.

254. See sources cited supra note 253. 
have been replaced by increasing numbers of passive overseas investors and short-term shareholders and traders. ${ }^{255}$ The "absentee landlords," as Lord Myners has also characterized shareholders, are disappearing. ${ }^{256}$ The effect of this was first felt in the area of takeovers, where hedge funds have become increasingly influential players in recent years as institutional investors have sold to them at the first sign of a bid. More and more, the outcome of a bid is now determined by arbitrageurs rather than persons with long-term engagement with the company-whether shareholders or the board. ${ }^{257}$ This has increased the distorted role of the takeover panel in removing board discretion at the point where the board may need to actively protect the interests of the corporation.

As shown earlier, those traditional institutional investors remaining in the listed market have been increasingly drawn to the attractions of trading shares rather than holding shares for any significant period. ${ }^{258}$ These changes in shareholders' strategies in trading, the increasing use of high-technology algorithmic trading (robots), the fragmentation of liquidity across multiple trading exchanges, and the resulting increased volatility have engaged a further dematerialization of the corporation itself and a dematerialization of the share, as shareholding periods have plummeted, particularly in the wake of high-technology trading strategies. ${ }^{259}$ By 2010, the Bank of England estimated that $50 \%$ of total trading volume in U.S. and European equities was algorithmic with holdings lasting microseconds rather than years. ${ }^{260}$ As equity markets have ceased to be significant funders of companies, they have morphed into complex trading platforms where hedge funds and high-frequency and proprietary traders account for $72 \%$ of daily market turnover. ${ }^{261}$

The share and the underlying corporation is ceasing to matter except as an important volatility trigger because trading has become the main focus of equity markets without the concomitant benefit for corpo-

255. See sources cited supra note 253.

256. Lord Paul Myners, Speech at the Association of Investment Companies' Annual Meeting (Apr. 21, 2009).

257. KAY, INTERIM REPORT, supra note 117, at 13.

258. TREASURY COMM., supra note 34, at 64 .

259. BANK OF ENG., supra note 65, at 46; Andrew G. Haldane, Exec. Dir., Bank of Eng., Speech at the International Economic Association Sixteenth World Congress in Beijing: The Race to Zero 8 (July 8, 2011) (transcript available at http://www.bis.org/review/r110720a.pdf).

260. BANK OF ENG., supra note 65, at 46.

261. See KAY, FINAL REPORT, supra note 3, at ch. 2 (discussing the decline of equity market funding); id. at 38 (discussing daily trading figures). The Kay Review's final report was also particularly concerned with changing regulatory practice away from favoring trading over investment. $I d$. at 44. 
rations of raising cheap capital. ${ }^{262}$ Holding shares for the long term when they can be traded 40,000 times in the blink of eye seems rather quaint. ${ }^{263}$ As Wooley and Vayanos noted,

[t]here is no point in simply rubbishing "short-termism." Momentum trading can deliver quick results, giving fund managers the best hope of meeting the expectations of impatient asset owners. ... The saddest aspect of this is that long-term investors have been drawn into the momentum game.... When investors who should be patient join the momentum traders, prices are pushed even further away from fundamental values based on cash flow projections. This is despite the fact that it is cash flows that will be needed over future decades to pay pensions and insurance claims and to run charities. $^{264}$

At the other end of the scale, just as in the case of the banks, there are indications that strategic activism of short-term shareholders is becoming a broader problem. ${ }^{265}$

One potential response to the analysis above and the lessons we should have learned from the banking crisis about our shareholderoriented system is to point to the United Kingdom's recent "shareholder spring" as evidence of reformed shareholders engaging with the ideas of long-term stewardship of companies. ${ }^{266}$ Shareholders are behaving responsibly at last, or so the story goes. But all is not as it seems with the shareholder spring.

The shareholder spring illustrates how deeply the good-shareholder myth has pervaded our mindset despite the shareholder problems evident in the banking crisis and how those banking shareholder problems are becoming wider, systemic shareholder problems. ${ }^{267}$ As observed earlier in the case of banks, short-term-focused shareholders levered remunera-

262. See KAY, FINAL REPORT, supra note 3, at ch. 2; Haldane, supra note 50, at 11-12. There is also great concern in the United Kingdom about high-technology trading and a government review is currently underway. See generally The Future of Computer Trading in Financial Markets, DEP'T. FOR BUS. INNOVATION \& SKILLS, http://www.bis.gov.uk/foresight/our-work/projects/currentprojects/computer-trading (last visited Nov. 18, 2012).

263. Haldane, supra note 259 , at 5.

264. Paul Woolley \& Dimitri Vayanos, Investors Must Rediscover Their Patience, Fin. TIMES (Aug. 15, 2012), http://www.ft.com/cms/s/0/7ec40bb2-d654-11e1-ba60-00144feabdc0.html\#axzz23i a06W2J.

265. Brian R. Cheffins \& John Armour, The Rise and Fall (?) of Shareholder Activism by Hedge Funds, 14 J. AlternAtive INV., no. 3, 2012. For a discussion of the shareholder spring and its implications, see infra text accompanying notes 269-79.

266. Kate Burgess \& Dan McCrum, Boards Wake Up to a Shareholder Spring, Fin. TIMES, (May 4, 2012), http://www.ft.com/cms/s/0/a284e414-95ee-11e1-a163-00144feab49a.html\#axzz1u OdUHIkq.

267. For analysis of the shareholder problems evident in the banking sector, see supra Part II (“THE SHADOW”). 
tion policy to combine disastrously with boards in targeting short-term returns for shareholders, directors, and employees generally. ${ }^{268}$ This entailed, as we now know, enormous social costs.

During the 2012 shareholder meeting cycle in the United Kingdom, shareholders became unusually active on remuneration votes while an excited media described this activism as a "shareholder spring," referencing the previous year's "Arab spring" of regime-change uprisings. ${ }^{269}$ The general media portrayal of these shareholder rebellions has been in similarly hopeful tones of regime change and shareholders concerned with excess remuneration. ${ }^{270}$ But the activism has been focused on poor current-shareholder-focused performance of executives rather than on objection to high levels of pay. ${ }^{271}$ At the beginning of the United Kingdom's shareholder-voting season, Barclays-where employee bonuses totaled $£ 2.15$ billion, but shareholder returns amounted to just $£ 730$ million$31.4 \%$ of shareholders failed to support the chief executive's remuneration package despite frantic behind-the-scenes attempts to win over shareholders. ${ }^{272}$ This set the tone for the rest of the reporting season when many companies saw significant numbers of shareholders vote against the remuneration report. ${ }^{273}$ Despite only three successful non-

268. Id.

269. Burgess \& McCrum, supra note 266.

270. James Salmon, Now the Backlash over Fat Cat Pay: Furious Shareholders Reject Lavish Deals for City Bosses, DAILYMAIL (May 3, 2012), http://www.dailymail.co.uk/news/article2139253/Now-backlash-fat-cat-pay-Furious-shareholders-reject-lavish-deals-City-bosses.html.

271. James Salmon, Barclays Is Rocked by Shareholders Rebellion Over Bumper Bonuses, THIS IS MONEY (Apr. 27, 2012), http:/www.thisismoney.co.uk/money/news/article2136313/Barclays-rocked-shareholders-rebellion-bumper-bonuses.html\#ixzz23iif8.

272. $I d$.

273. At William Hill, $49.8 \%$ voted against the remuneration report, while the following percentages voted against the remuneration report at other businesses: $46 \%$ at Trinity Mirror, $44.3 \%$ at Easy Jet, $40 \%$ at Xstrata, $40 \%$ at Inmarsat, 37\% at UBS, 31.8\% at Cookson, 31.6\% at Credit Suisse, $30 \%$ at Smith and Nephew, 30\% at Prudential, 30\% at Capital Shopping Centres, 26\% at Tullow, $25 \%$ at XChanging, 23\% at Regus, $20 \%$ at Resolution, $17 \%$ at $888,17 \%$ at 3i, 15\% at Reckitt Benckiser, and 15\% at Man Group. See Jamie Dunkley, 3i Cuts More than 160 Jobs and Shuts Offices, TELEGRAPH (June 29, 2012), http://www.telegraph.co.uk/finance/newsbysector/banksand finance/privateequity/9364171/3i-cuts-more-than-160-jobs-and-shuts-offices.html; Alistair Gray, Pru Hits Back After Investors' Pay Revolt, FIN. TIMES (May 17, 2012), http://www.ft.com/cms/s/0/ 1e8abb9e-a01f-11e1-90f3-00144feabdc0.html\#axzz1vmD7AwAQ; Terry Macalisiter, Dan Milmo \& Jill Treanor, Cairn Energy Faces Shareholder Rebellion Over Pay, GUARDIAN (May 17, 2012), http://www.guardian.co.uk/business/2012/may/17/cairn-energy-shareholder-rebellion-pay; Simon Neville, William Hill Chief's Pay Deal Survives Shareholder Revolt by a Nose, GUARDIAN (May 8, 2012), http:/www.guardian.co.uk/business/2012/may/08/william-hill-shareholder-revolt-pay; Graham Ruddick, Shareholder Spring: Investor Revolts at Tullow Oil and 888, TELEGRAPH (May 16, 2012), http://www.telegraph.co.uk/finance/newsbysector/energy/oilandgas/9270670/ShareholderSpring-investor-revolts-at-Tullow-Oil-and-888.html; Jonathan Russell, Shareholder Spring Clocks up Three More Casualties, TELEGRAPH (May 17, 2012), http://www.telegraph.co.uk/finance/newsby sector/industry/9272005/Cookson-suffers-investor-revolt-and-considers-splitting-in-two.html; Mark Sweney, Trinity Mirror Boss Sly Bailey Narrowly Survives Shareholder Revolt over Pay, GUARDIAN 
binding protest votes on remuneration reports in the past decade (RBS, Shell, and GlaxoSmithKline), by mid-June 2012 at Central Rand Gold, Pendragon's, Cairn, Aviva, Centamin, and WPP, 75\%, 67\%, 67\%, 60\%, $64 \%$, and $50.1 \%$ of shareholders respectively voted against the companies' remuneration reports. ${ }^{274}$ At Aviva, ${ }^{275}$ AstraZeneca, ${ }^{276} 3 \mathrm{i},{ }^{277}$ and Trinity Mirror, ${ }^{278}$ protest votes and wider remuneration concerns triggered the resignations of four chief executives in the run-up to the votes. ${ }^{279}$

These activist votes are undoubtedly an unusual public engagement with executive pay, but they had a number of novel features in 2012. First, the activist campaign by Fairpensions targeting pension trustees through Yoursayonpay.org.uk were very successful in engaging the public directly to pressurize U.K. pension and saving providers to vote on remuneration reports. Second, political pressures on U.K. institutional investors to vote on pay were enormous. On May 9, just before the main AGM season, the U.K. government announced plans to introduce a compulsory vote on remuneration. ${ }^{280}$ As a result, the actions of U.K. institu-

(May 10, 2012), http://www.guardian.co.uk/media/2012/may/10/trinity-mirror-sly-bailey-survivespay; Jill Treanor, Xstrata and Man Group Hit by Investor Protests Against Boardroom Pay, GUARDIAN (May 1, 2011), http://www.guardian.co.uk/business/2012/may/01/xstrata-man-groupinvestor-protests-pay; Harry Wallop, Regus Hit by Shareholder Spring, TELEGRAPH (May 16, 2012), http://www.telegraph.co.uk/finance/newsbysector/retailandconsumer/9268048/Regus-hit-by-shareho lder-spring.html.

274. Jill Treanor \& Jullia Kollewe, Aviva Shareholders Revolt Over Boardroom Pay, GuARDIAN, May 4, 2012, at 26; Jamie Grierson, Shareholders Vote Against WPP Boss Pay Package, INDEPENDENT (June 13, 2012), http://www.independent.co.uk/news/business/news/sharehold ers-vote-against-wpp-boss-pay-package-7848342.html; Macalisiter, Milmo \& Treanor, supra note 273; Emma Rowley, Shareholder Spring Continues with Pay Revolt at Centamin, TELEGRAPH (May 30, 2012), http://www.telegraph.co.uk/finance/9301118/Shareholder-Spring-continues-with-payrevolt-at-Centamin.html.

275. Andrew Hill, Performance Not Pay Doomed Aviva's Moss, Fin. Times Bus. Blog (May 8, 2012), http://blogs.ft.com/businessblog/2012/05/performance-not-pay-doomed-avivas-moss/\#axzz 1v7HbxXEp.

276. Andrew Jack \& Kate Burgess, AstraZeneca Chief Brennan to Retire Early, Fin. TimES (Apr. 26, 2012), http://www.ft.com/cms/s/0/50399e1e-8f6a-11e1-98b1-00144feab49a.html\#axzz 1v7E5GIly.

277. Dunkley, supra note 273.

278. Ben Fenton, Salamander Davoudi \& Kate Burgess, Sly Bailey to Leave Trinity Mirror, FIN. TIMES (May 3, 2012), http://www.ft.com/cms/s/0/c0129fc6-953f-11e1-8faf-00144feab49 a.html\#axzz1v7E5GIly.

279. Alistar Gray, Moss Quits After Pay Revolt at Aviva, Fin. Times (May 8, 2012), http://www.ft.com/cms/s/0/dc4b1966-98d7-11e1-9da3-00144feabdc0.html\#axzz1v7E5GIly.

280. See Dep't. for Bus. InNovation \& Skills, Executive Pay: Shareholder Voting RIGHTS CONSULTATION (2012), available at http://www.bis.gov.uk/assets/biscore/businesslaw/docs/e/12-639-executive-pay-shareholder-voting-rights-consultation.pdf; Louisa Peacock, Businesses Raise Doubts Over Vince Cable's Pay Proposals, Telegraph (Jan. 23, 2012), http://www.telegraph.co.uk/ finance/jobs/9034062/Businesses-raise-doubts-over-Vince-Cables-payproposals.html. 
tional investors both served to portray empathy with public anger on pay and send a signal to the government that the legislation introducing mandatory say on pay was unnecessary. ${ }^{281}$ Third, regulatory changes in the United States strongly impacted this reporting season, requiring U.S. investors to vote their overseas shares. ${ }^{282}$ As U.S. investors are the largest group of foreign investors, this had a magnifying effect on the protest votes. ${ }^{283}$ Fourth, and probably most importantly, the remuneration votes morphed from "say on pay" into a "say on board strategy" if boards failed to concentrate on the interests of short-term shareholder. ${ }^{284}$ In recent years, return on equity performance has been poor, while salaries have been rising after a brief pause in the immediate aftermath of the financial crisis. ${ }^{285}$

While the pension-activist campaign was a genuine protest on high elite pay, and other shareholders had regulatory obligations or attempted to avoid regulation, some of the key shareholder actions represent activist shareholders' utilization of the coalition of votes on the remuneration report to affect the strategic direction of the company, rather than attacks on high pay. For example, Barclays' reaction to the protest vote, after much negotiation with shareholders, was to agree to focus more closely on returns to shareholders rather than on pay reduction. ${ }^{286}$ At Cookson, the pay revolt was part of a wider activist-fund attempt to focus management on short-term returns to shareholders by splitting up the company and giving the fund a seat on the board. ${ }^{287}$ The chief executive of $3 \mathrm{i}$ resigned under pressure from activist investors before the AGM remuneration vote, and the company then announced a new strategic direction that focused on current returns to shareholders. ${ }^{288}$ Similarly, Astrazeneca's chief executive resigned under pressure from shareholders

281. Nils Pratley, Shareholder Rebels with a Cause, GUARDIAN (May 3, 2012), http:/www.guardian.co.uk/business/blog/2012/may/03/company-shareholder-revolts-boardroompay.

282. Dan McCrum, Shareholders Lose Patience on Bankers' Pay, FIN. TIMES (Apr. 20, 2012), http://www.ft.com/cms/s/0/83bbffd8-8a66-11e1-93c9-00144feab49a.html\#axzz1scdG3c3J.

283. DIGNAM \& GALANIS, supra note 169 , at $400-01$.

284. See infra text accompanying notes 286-90.

285. High Pay Comm'n, Cheques with Balances: Why Tackling High Pay Is in the NATIONAL INTEREST 40 (2011), available at http:/highpaycommission.co.uk/wp-content/uploads/ 2011/11/HPC_final_report_WEB.pdf.

286. Matt Scuffham \& Katharina Bart, Credit Suisse and Barclays Investors Revolt over Pay, REUTERS (Apr. 27, 2012), http://uk.reuters.com/article/2012/04/27/uk-barclays-creditsuisse-agmidUKBRE83Q0B020120427.

287. Russell, supra note 273.

288. Stanley Pignal, New 3i Chief Pledges Shareholder Payouts, FIN. TIMES (May 17, 2012), http://www.ft.com/cms/s/0/53540ae2-9fed-11e1-94ba-00144feabdc0.html\#axzz1v7E5GIly; Tanya Powley, 3i Set to Appoint Ex-City Banker as Chief, FIN. TIMES (May 13, 2012), http://www.ft.com/ cms/s/0/a712be6a-9d01-11e1-9327-00144feabdc0.html\#axzz1v7E5GIly. 
in the buildup to the 2012 AGM remuneration vote because of his specific strategic focus on long term $R \& D$ and the expectation that a new chief executive would refocus the company on returning cash to shareholders. ${ }^{289}$ Likewise, the board resignations at Trinity Mirror and Aviva reflected this pattern. ${ }^{290}$

The votes on remuneration during this shareholder spring have allowed some shareholders the opportunity to remove executive directors and affect strategic direction when separate, formal votes on the removal of an executive director or on a change of strategy would almost certainly fail. ${ }^{291}$ Say on pay votes have become a Trojan horse within which short-term strategies can be engaged because of the coalition that forms behind remuneration votes. ${ }^{292}$ Just as in the case of the bank failures, some shareholders are using remuneration as a key tool to influence the strategic direction of companies in a way that runs strongly counter to the ideal of stewardship. ${ }^{293}$

\section{CONCLUSION}

The banking crisis revealed a core corporate governance problem in terms of shareholder-board interaction, as shareholders encouraged huge risk taking in the banking sector and boards went along for the wellremunerated ride. This Article has argued that stewardship and shareholder empowerment as a reform mistakenly characterize shareholders as willing and responsible owners when there is little evidence of this. In the bank failures, activism, not passivity, was a significant problem, and the result has been devastating for the private and public sector. Despite this, very little broad corporate governance reform has occurred for banking. Mervyn King's statement in 2009 remains apposite today: "To paraphrase a great wartime leader, never in the field of financial endeavor has so much money been owed by so few to so many. And, one might add, so far with little real reform." ${ }^{, 294}$ While at the EU level there have been oversight reforms for banking regulation, ${ }^{295}$ King's observation re-

289. Jack \& Burgess, supra note 276.

290. Jamie Dunkley, Aviva Forced to Axe Chief Executive Andrew Moss's Pay Rise, TELEGRAPH (Apr. 30, 2012), http://www.telegraph.co.uk/finance/newsbysector/banksandfinance/in surance/9236856/Aviva-forced-to-axe-chief-executive-Andrew-Mosss-pay-rise.html; Sweney, supra note 273 .

291. See sources cited supra note 290.

292. See sources cited supra note 290.

293. See sources cited supra note 290.

294. King, supra note 30 , at 3.

295. See Niamh Moloney, Reform or Revolution? The Financial Crisis, EU Financial Markets Law and the European Securities and Markets Authority, 60 INT'L. \& COMP. L. Q. 521 (2011); Francois Laurens, UK Banking Regulatory and Market Framework: Post-Crisis Reform (July 18, 2012) (working paper), available at http://ssrn.com/abstract=2112934. 
mains largely true at the domestic level despite the reports and reviews led by Turner, Vickers, Walker, Kay, and the Treasury. As a result, we know a lot about what went wrong but have done little about it. ${ }^{296}$

Partly, this is true because one clear solution to ownership and control issues was forced on the British state as a result of the bailout. That is, much of the former private banking sector is in effective state ownership now. This situation is not likely to change any time soon as primarily the party with residual liability for the risks - the state- now controls risk taking. There is a general salutary lesson in this forced solution for banking-sector reform. Risk tends to remain under control when those taking the risk have liability for it. Retail banks can be regulated through capital ratios and a state guarantee, but casino-like investment banking does not warrant such a state guarantee, and ratios will never come close to providing a safe cushion unless they are raised enormously. The simple answer would be to focus on risk control in an organizational sense rather than in a multi-instrumental one-completely split retail from investment banking, not an internal "ringfence" but a total separation-and allow investment banking only through partnership as a legal form.

Investment banks seem to be badly suited to operate through riskenhancing limited liability corporations, particularly ones that are listed on and subject to the market forces of the secondary market. Once upon a time, investment banks operated successfully as partnerships. This acted as both a technical and cultural risk-control mechanism. The usefulness of this organizational form remains today but is largely outside the mainstream reform debate. We remain a significant distance from real organizational reform of the U.K. private banking sector despite further scandals since the financial crisis, which revealed a continuing and seriously dysfunctional corporate culture. ${ }^{297}$ Without organizational reform, the Merton model will continue to exert its siren call to private sector banks.

Although the United Kingdom and United States are often bundled together as forming an Anglo-Saxon corporate governance system, they are significantly different in two ways. First, as we have observed above, shareholders have much more power in the United Kingdom than in the

296. In the United Kingdom, the regulatory framework is slowly changing, and the U.K. government intends to "ringfence" the retail and investment parts of U.K. banks in an attempt to solve the problem of the state guarantying investment-banking risk. See Reforming the Regulatory Framework, BANK OF ENG., http://www.bankofengland.co.uk/financialstability/Pages/overseeing_fs/ default.aspx (last visited Feb. 23, 2013); see also Rt. Hon George Osborne MP, Chancellor of the Exchequer, Speech on the Reform of Banking (Feb. 4, 2013) (transcript available at http://www.hmtreasury.gov.uk/speech_chx_040213.htm).

297. See Michael Rothfeld, David Enrich \& Jay Solomon, Barclays in Sanctions Bust: U.K. Firm to Pay \$298 Million to Settle Charges Involving Iran, Libya, Cuba, Wall St. J., (Aug. 17, 2010), http://online.wsj.com/article/SB10001424052748703908704575433781894978828.html; Libor Scandal, FIN. TIMES (Nov. 12, 2012), http://www.ft.com/indepth/libor-scandal. 
United States. ${ }^{298}$ Unlike Kahan and Rocks's Embattled CEOs, U.K. CEO's have little board independence to fight back with, and so they are perhaps uniquely vulnerable to shareholder activism. ${ }^{299}$ The second difference is perhaps deeply cultural: there is an expectation in the United Kingdom and in Europe generally that companies and shareholders should behave responsibly. ${ }^{300}$ Referring to the Dodd and Berle debate on the 1930s, Professor Gower explained to a U.S. audience in 1955:

So far at any rate as England is concerned public opinion seems to have hardened in favor of Dodd's view, so that it has become almost an accepted dogma that management owes duties to "the four parties to industries" (labor, capital, management, and the community) - a dogma which is repeated indiscriminately in the speeches of right-wing company chairmen and left-wing politicians. ${ }^{301}$

The pendulum, in terms of the strength of this dogma, has swung back and forth over time, but in a comparative sense to the United States, the expectations of policymakers, regulators, the general public, and the academy that shareholder engagement retain a core focus on responsibility is strong. ${ }^{302}$ Indeed, the U.K. Companies Acts prefers the term member rather than shareholders to describe equity holders. ${ }^{303}$ Member probably more accurately conveys the expectation that we have for shareholders to participate in the corporation, abide by the rules, and behave responsibly. We assume at the policy level that shareholders want to be good, if only they could. And if they are not, there must be some technical impediment to unleashing their goodness. This is a dangerous mindset given the reality of our shareholder class, and so we latch onto illusory concepts such as stewardship provided by the Walker and Kay Reviews.

As Cheffins stated in 2011 considering the financial merits of shareholder engagement,

298. See supra Part III ("Vulnerable BoARds"); see also Jennifer G. Hill, The Rising Tension between Shareholder and Director Power in the Common Law World, 18 CORP. GOVERNANCE: INT'L REV. 344 (2010).

299. Marcel Kahan \& Edward B. Rock, Embattled CEOs, 88 TEX. L. Rev. 987, 1051 (2010).

300. See, e.g., Co. LAW ReVIEW SteEring GrP., supra note 242; A Renewed EU Strategy 2011-14 for Corporate Social Responsibility, COM (2011) 681 final (Oct. 25, 2011), available at http://eur-lex.europa.eu/LexUriServ/LexUriServ.do?uri=COM:2011:0681:FIN:EN:PDF.

301. Gower, supra note 164, at 1190.

302. For example, as discussed earlier the Company Law Review Steering Group's recommendations to clarify that directors' duties include stakeholder considerations led to the enactment of section 172 of the Companies Act 2006. See Co. LAW ReVIEW SteERING GrP., supra note 242, at ch. 3 .

303. See, e.g., Companies Act, 2006, c. 46 (U.K.).. 
[i]f calls are made for a more intrusive approach to shareholder engagement, it would be prudent for policymakers to scrutinize carefully an assumption that has gone largely unquestioned as debates about corporate governance have proceeded in the UK, namely that shareholder involvement in corporate affairs generates net benefits. Though those vested with responsibility for reforming UK corporate governance have generally assumed shareholder activism is a 'good thing,' the point should not be taken for granted. ... Moreover, empirical studies of shareholder activism by mainstream institutional shareholders on the long-term operating performance of companies virtually all report no statistically significant improvement. ${ }^{304}$

Shareholders will apparently be good now that we have pointed the way to a long-term focus through stewardship. But nebulous fixes to a core systemic design flaw are unlikely to prove successful in the face of an agency-cost-reducing regulatory system anchored by a currentshareholder-focused takeover panel. Add in a reflective culture of shareholder ownership, dematerialized trading robots, and short-term-focused shareholders, and we have created - or rather, within the United Kingdom's self-regulatory context we have allowed shareholders to create- a dangerously imbalanced system of ownership and control.

So what should we do to fix this mess? Stewardship and increased shareholder-engagement provisions, such as mandatory say on pay, offer nothing new save the unlikely hope that shareholders suddenly behave responsibly in a marketplace full of incentives to do otherwise. Rather, we should begin again without the aid of agency-cost theory, ${ }^{305}$ recognizing that shareholders have become part of the problem rather than the solution. The United Kingdom's unusual unipolar corporate governance system has created enormous incentive distortions for shareholders to grab "jam today," while like the White Queen, self-regulatory stewardship reform, offers the vague possibility of "jam tomorrow" if you are good. ${ }^{306}$ Jam tomorrow will never rival jam today for real shareholders, and the robots are programmed to seek only today's fresh jam. Like Alice's reaction, it all leads to confusion and, in the cases of the banks, to huge social cost. Instead, we need to rethink the shape of our corporate governance system starting with removal of key foundational distortions like the takeover code and the Panel. Our judiciary would then have the opportunity to put real flesh on the bones of the directors' section 172 duty, and we would find out if it can give the board the ability to take a

304. Cheffins, supra note 2 , at 40-41.

305. Even Michael Jensen considers current-incentive aspects of agency-cost reduction to be problematic. See PAUl R. KRUGMAN, THE CONSCIENCE OF A LIBERAL 148 (2007).

306. CARROLL, supra note 1. 
much longer-term approach as the Kay Review mistakenly believes it currently does. ${ }^{307}$ In the U.S. context, Lynn Stout explained:

Conventional shareholder primacy stands on the brink of intellectual failure. To survive it must evolve into a new, more complex, and more subtle understanding of what shareholders really want from corporations. This understanding acknowledges that it may be impossible to define the "purpose" of the corporation in terms of a single, easily measured goal, and that the objective of any particular corporation may be best determined not by regulators, judges, or professors, or even by any individual shareholder or group of shareholders, but by a board of directors. ${ }^{308}$

There is some hope in this because the U.K. judiciary is deeply attached to the materialization of the company and the protection of a balanced board discretion to manage the company. ${ }^{309}$ If implemented, the Kay Review's recommendations ${ }^{310}$ on long-term remuneration incentives (to allow long-term shares only) and short-term financial disclosure distortions (to remove quarterly financial disclosure obligations) would also assist in removing other problematic agency-cost-reducing measures. In the United Kingdom, rebalancing board power will take time, and we will need that time because the directors we currently have at the top of our largest companies may not have the skills needed to run those companies as independent entities. Directors who have risen to the top in a current-shareholder-focused corporate governance system that limited their discretion to manage over the past thirty years likely hold a very different set of skills than those needed to make independent decisions on what is best for the company. It will take time to work through the board production system.

These technical changes would achieve a rebalancing in terms of the relationship between the shareholders and the board. It would not be a return to, as Gower described it above, "'the four parties to industry" (labor, capital, management, and the community)." "311 To achieve real balance of corporate power inside and outside of British corporations, those four parties need to be renewed and respected as they once were. But to do that, the state needs to reclaim its mediating role in protecting labor, management, and the community. Weak worker influence and declines in individual labor protection and unions are directly connected to

307. KAY, FINAL REPORT, supra note 3, at 17.

308. LyNn STOUT, THE SHAREHOLDER VALUE MYTH 115 (2012). BOARDS").

309. See Adams v. Cape Industries PLC, [1990] Ch. 433 (A.C.); supra Part III ("VulNERABLE

310. KAY, FINAL REPORT, supra note 3, at ch. 11.

311. Gower, supra note 164. 
the decline of the state in the United Kingdom. Community influence is similarly weak when not voiced through state power, while board power has been stripped away as described throughout this Article. Yet governments have hollowed out the state from the left, the right, and the middle of the political spectrum in the United Kingdom, and its powerful positive role in the corporate economy has been articulated only by those ghettoized as the hard left. Once upon a time, as Gower explained above, even right-wing chairmen of British companies understood the importance of balanced duties to constituencies other than shareholders. ${ }^{312}$ Without a wider reinvigoration of the state's role, the best we can achieve are Dodd-esque board mediators of the public good backed up by a judicially interpreted, balanced discretion. That will be better than our current lot, and indeed, board mediating/representative/independent models currently have normative momentum through advocates such as Blair, Stout, ${ }^{313}$ Greenfield ${ }^{314}$ and Bainbridge. ${ }^{315}$ But without a wider mediating state, board mediation risks the pendulum swinging back to boards dominated by powerful managers and Berle's fears of a powerful unaccountable managerial class being realized.

Ironically, as we have seen in the banking bailouts, capitalism's future may depend on the state. By the late 1980s, even Robert Nozick considered the pendulum to have swung too far against the state in terms of the collective versus the individual. ${ }^{316}$ So how do we reinvent the state as a positive force?

As argued within this Article, we start by removing agency-costreducing initiatives and reinvigorate judicial oversight of board discretion. Wider changes would include improving collective and individual labor laws, investing in and planning the economy as a partnership with industry, prioritizing environmental protection, introducing community-

312. Id. at $1192-93$

313. See Margaret M. Blair \& Lynn A. Stout, Director Accountability and the Mediating Role of the Corporate Board, 79 WASH. U. L. Q. 403 (2001); see also Margaret M. Blair \& Lynn A. Stout, A Team Production Theory of Corporate Law, 85 VA. L. REV. 247 (1999); Margaret M. Blair \& Lynn A. Stout, Team Production in Business Organizations: An Introduction (Geo. U. Law Ctr., Bus. Econ. \& Regulatory Law Working Paper No. 180991, 1999), available at http://ssrn.com/ab stract $=180991$.

314. Kent Greenfield, Public Lecture at Queen Mary School of Law: The Company Board as Regulatory Body (Feb. 21, 2013).

315. See Stephen M. Bainbridge, Director Primacy and Shareholder Disempowerment, 199 Harv. L. Rev. 1735 (2006); Stephen M. Bainbridge, Director Primacy: The Means and Ends of Corporate Governance, 97 Nw. U. L. REV. 547 (2003); Stephen M. Bainbridge, Director v. Shareholder Primacy in the Convergence Debate, 16 TRANSNAT'L LAW 45 (2002). For a good overview of the board primacy models and an interesting entrepreneur model, see Charles R.T. O'Kelley, The Entrepreneur and the Theory of the Modern Corporation, 31 J. CORP. L. 753, $772-77$ (2006).

316. Stephen Metcalf, The Liberty Scam, SLATE (June 20, 2011), http://www.slate.com/art icles/arts/the_dilettante/2011/06/the_liberty_scam.html. 
consultation obligations, and implementing strongly progressive individual and corporate taxation. The agenda is not difficult; realizing it is another matter. First, none of the mainstream U.K. parties are interested in a significant mediating role for the state. ${ }^{317}$ Without it, we risk at best moving between one unbalanced corporate governance system to another-Dodd to Berle, Berle to Dodd - doomed to repeat the mistakes of history again and again. At worst, we risk eroding capitalism's future by perpetuating and exporting the underlying corporate governance causes of the financial crisis to companies generally resulting in an even larger future crisis. Second, we lack a proper terminology to capture what shareholding has become, and we cling to words such as owners and stewards that we think imply homogeneity and responsibility. Words are not simply words. They are illustrative of culture and mindset. Even in what seem like the good old days, institutional investors were at best passive and at worst simply exited rather than engaged in a stewardship role. Those days of traditional institutional shareholders are passing, as are our anchor U.K. shareholders, to be replaced by über-passive overseas shareholders, activist shareholders, traders, and robots. Our vocabulary, like our regulatory system, is not built to encompass this change as we continue to fight the last war, facing east, confident that our Maginot Line of stewardship and shareholder empowerment will hold. ${ }^{318}$ It will not.

317. Owen Hatherly, Jim Murphy's Dangling of Middle-Class Mobility is a Rat Race for the Few, GUARDIAN (Oct. 5, 2012), http://www.guardian.co.uk/commentisfree/2012/oct/05/jim-murphymiddle-class-mobility; Lord Wood of Anfield, The Crisis of Conservative Values, TELEGRAPH (Oct. 5, 2012), http://www.telegraph.co.uk/news/politics/9590820/Lord-Wood-of-Anfieldthe-crisis-ofConservative-values.html; Our Constitution, LiBerAL DEMOCRATS, http://www.libdems.org.uk/cons titution.aspx (last visited Nov. 18, 2012).

318. ANTHONY KemP, The MAginot Line: Myth And ReALity 24 (1982). 